\title{
Det hele menneske og en kristologisk funderet forsynstanke: Om brugen af "Sjæl" og "Støv" i to grundtvigsalmer
}

\author{
Af Aage Schiøler
}

Afhandlingen afdækker, hvordan brugen af elementer fra GT i Grundtvigs salmedigtning indvirker på beskrivelsen af menneskelivets eksistentielle vilkår og på formuleringen af den kristologiske dynamik i hans forsynstanke. Som hovedtekster bruges "Han, som har hjulpet hidindtil", 1848-51 (GSV IV, 272-273), og "Hjertesuk efter Davidsharpen", 1855-56 (GSV V, 28). Undersøgelsen inddrager desuden enkelte andre tekster fra GSV til belysning af Grundtvigs brug af elementer fra antropologien i GT, mens der kun lejlighedsvis inddrages prosatekster. ${ }^{1}$

\section{Eksempler på Grundtvigs brug af "Sjoel” og "Støv" $i$ salme- digtningen}

Som indledning til analysen af hovedteksterne bringes nogle eksempler på Grundtvigs brug af "Sjæl" og "Støv" som betegnelser for det hele menneske. Deres samvirke gennem menneskets sangevne ved modtagelse og gengivelse af Gudsordets frisættende tiltale markeres. ${ }^{2}$

\section{Varianter i sprogbrugen for "Sjæl" og "Støv"}

De fleste er fortrolige med vendinger som: "Der var ikke et øje i butikken" og den lidt ældre: "Der var ikke en sjæl i huset". Både sjæl og øje taler om det hele menneske. Brugen af sjæl på denne måde svarer til 1 Mos. 2,7: "Da formede Gud Herren mennesket af jord og blæste livsånde $\mathrm{i}$ hans næsebor, så mennesket blev et levende væsen", hvor oversættelsen på Grundtvigs tid lød: "en levende Siel" ( $A O$ 1740). ${ }^{3}$ Et kort eksempel på denne brug hos Grundtvig er:

I dit Navn gienfødes Sjæle,

I dit Navn Guds Engle knæle!

(GSV IV, str. 1, 472)

hvor de levende væsener på jord og i himmel stilles over for hinanden. Det legemlige ved sjælen, menneskets positive indfældethed i naturen ville vi vel sige i dag, ser vi gennem udtrykket "Som Soel gaar ned (...), / Saa gaaer den Sjæl til Hvile (...)" knyttet til solens nedgang "bag Lunden / I Havet lyseblaat" (GSV V, str. 2, 212; VI/3, 406, sp. 2).

Det svarer til, at vi i linjerne "Sol opstaaer, / og Sol nedgaaer, / Naar den har gjort sin Gierning. / Gud give os at skinne saae, (...)" (GSV IV, str. 5, 338) møder solens daglige vandring som parallel til den menneskelige mulighed for aktivt at indgå i omgivelserne. I den 
foregående strofe kunne det jo uden betydningsændring have heddet "Gaae da frit / Hver Sjoel til sit, / (...)".

I "Lovsynger Herren, min Mund og mit Indre", Grundtvigs gendigtning af Sl 103, kombineres fysik og psyke, så de sammen dækker det hebraiske nœfoesj. I str. 1 er glosen gengivet ved "min Mund og mit Indre", sjælens udadvendte og indadvendte side. I str. 2 bruges den sædvanlige gengivelse "Sjæl", men den beskrives karakteristisk som det væsen, der i én handling bruger sig selv psykisk ved at huske og fysisk ved at synge med lunger, stemmebånd, tunge og læber: "Sjæl! Kom ihu, at Hans Pris du forkynder (...)". Helt kort siges det samme i "Alt hvad som Fuglevinger fik":

Min Sjæl, du har af alt paa Jord
I Tanken og din Tunges Ord
De allerbedste Vinger (...)
(GSV IV, str. 2, 290)

Et andet dobbeltudsagn om mennesket som udelt livsvæsen møder vi i salmen "Min Mund og mit Hjerte" (GSV I, 264-65; V, 498-99), hvor "Mund og (...) Hjerte" i str. 1 er det hele menneske, der viderebringer udadtil, hvad det indadtil har modtaget udefra. "De gjorde en Pagt", og pagtens indhold er de to parters sammenhold om åbent at vedstå det fælles, gudgivne liv under ethvert vilkår: "I Fryd og i Smerte". Guds kærlighedsgave, selve livet, gælder både "Hjerter og Munde". Sammen har de modtaget "Ordet, som frelser fra Død" (GSV V, str. 2, 498). Glæden over det må de derfor også være sammen om (GSV I, str. 4, 290. GSV V, str. 4, 499). Selv om glosen "Sjæl" ikke forekommer, er det tydeligt, at der synges om "en levende siel" i betydningen fra 1 Mos 2,7, helt parallelt med brugen i "Lovsynger Herren (...)", str. 1-2. Det er også karakteristisk, at Grundtvig i salmen "Op til Guds Huus vi gaae" $(G S V \mathrm{~V}, 171-172) \mathrm{i}$ et udateret håndskrift har haft "Vor Krop er døv og stum / For Evangelium" i str. 3 (GSV VI/3, 397, sp. 2n). "Sjæl” kommer først med ved offentliggørelsen i Dansk Kirketidende i 1857, muligvis for at undgå den vildfarelse, at kroppen skulle være mindre gudvelbehagelig og mindre lydhør over for Guds ord end sjælen. Paralleliteten mellem krop og sjæl fremgår åbenlyst af str. 4:

Guds Ord til Sjæl og Krop

Han siger selv: Luk op!

Også her anfører jeg håndskriftets ordvalg "Han”, hvoraf det fremgår, at "Guds Ord" er synonym for Kristus selv (Johs 1, 14). Hvor det ord lyder, det vil sige hvor Kristus er og taler, sker der det, at "Tungen svarer ja!" (str. 5), og "vort Bryst" tager imod tiltalen, i dette tilfælde helt konkret ved at lære og bruge Fadervor:

Saa lærer os Guds Søn

Sin egen Barnebøn,

Indaander i vort Brvst 
Sin egen Barnerøst

(str. 6)

"Tunge" og "Bryst" er synonyme med "Mund" og "Hjerte" $\mathrm{i}$ "Min Mund og mit Hjerte" og med "Mund" og "Indre" i "Lovsynger Herren". "Tanken og din Tunges Ord" fra "Alt hvad som Fuglevinger fik" falder også ubesværet ind i dette syn på mennesket som et helt væsen, set på to uadskillelige måder.

I et digt om Kødets Opstandelse fra først i 1860'erne hedder det meget markant om hjertet som repræsentant for legemlighedens nødvendighed $\mathrm{i}$ et ægte menneskeliv:

Hjerteløs den Sjæl maa være,

Følesløs for Livets Ord,

Som sit Legem vil undvære

Hvor for evig Sjælen boer

Hjertets Banken, Hjerte-Røsten,

Hjertens-Glæden, Hjerte-Trøsten,

Hvad var Livet, skilt ved dem!

$(G S V \mathrm{~V}$, str. 4, 368)

Klarere kan det næppe dokumenteres, at legeme og sjæl for Grundtvig er uadskillelige og ligeværdige udtryk ved betragtningen og beskrivelsen af menneskelivet.

\section{"Sjæel" og dødning}

Et karakteristisk tilfælde findes $i$ et ejendommeligt digt fra cirka 1860 om nedfarten til "Dødningehjem" (GSV V, 356-57). Selv om digteren erkender, at det hjem ikke kan beskrives "med denne Verdens Ord" (str. 1), hedder det dog:

Kun det er klart, vi troe derpaa,

At mens i Grav hans Legem laae,

Hans Sjæl var dog i Aande!

(str. 1, 5-7)

At "i Aande" ikke drejer sig om en luftig, ubestemt værensform, fremgår af, at udtrykket må vise tilbage til Guds virkeform i 1 Mos 1,2 og 2,7, der gør verden til levested og mennesket til livsvæsen. Det viser sig også i, at når Kristi "rene Sjæl paa Sjæle-Viis / Sig rørde end med Størke" (str. 2, 1-2), bevirker det,

At i de Dødes Rige

Dog Livets Ord fandt Vei og Røst

Og Hørelse tillige

(str. 4, 2-4)

Vej, røst og hørelse hører til legemligheden. Derfor kan det i næste strofe lyde om hedningerne, der levede før Kristus:

Men deres Siæl var dog ei glemt 
Til Dødninger i Løndom giemt

Var Livet af Guds Naade!

(str. 5, 5-7)

selv om deres tilværelse på jorden endte "Som Bækkenes i Ørken" $(5,2)$, det vil sige forsvandt under jordens overflade.

Som også digtets første linje angiver, er sjælene altså "Dødninger". Dem kender vi andetsteds fra hos Grundtvig. Nævnes kan et par linjer fra salmen "Christus den Lyslevende" fra 1843, i 1847 omdigtet under titlen "Den levende Christus", nu med henvisning til Johs 14,19: "Endnu en kort tid, og verden ser mig ikke længere, men I ser mig, for jeg lever, og I skal leve". Her tales der om

\section{(...) Dødninger i Taagedal \\ I Hvilen og i Vaanden \\ (GSV III, str. 4, 229; IV, str. 3, 224)}

Hvile og vånde knytter sig til menneskelivets fysiske aspekt, især når man betænker 1 Mos 3, 16-19. Her beskrives konsekvenserne af, at mennesket forgreb sig på kundskabstræets frugter: smerten ved barnefødsler, det hårde slid for brødet og sluttelig genforeningen med den jord, mennesket er taget af. Også salmen "I Kvæld blev der banket paa Helvedes Port" (GSV I, 471-474) hører til i den sammenhæng. I str. 9:

Sig reiste de Fanger nu alle paa Stand,

Men kun for dybt at nedknæle,

Velkommen, velsignet, vor Frelser-Mand!

Det lød fra utallige Sjæle!

møder vi sjæl/sang/støv-konstellationen, der omtales senere. Sjælen er omtalt direkte. Sangmotivet ses i linjen: "Velkommen, velsignet, vor Frelser-Mand!", der bedst høres som genklang af Sl 118, 26: "Velsignet være han, som kommer, i Herrens navn", som også lyder under Jesu indtog i Jerusalem (Matt 21, 9par). Strofens brug af legemligheden svarer til de associationer, der knytter sig til dødning: Fangerne rejser sig op og knæler ned. "Støvet" er der, selv om glosen mangler.

I alle tre digte findes udtryk for, at de døde fysisk er spærret inde, som det fremgår af følgende udtryk: "(...) det store Fangenskab" (GSV V, str. 2, 356), "Helhjems Port" (GSV III, str. 4, 449, IV, str. 3, 224) og "Helvedes Port" (GSV I, str. 1, 471). De døde er på den måde påfaldende mere i slægt med de gengangere, man i fordums tid måtte fæste i mosen med pæle, end med de flygtige gespenster, som ved nattetid siver gennem mure og døre i gamle borge og slotte. Selv i disse til os ukendte egne henlagte digte synes en levende sjæl uden fysisk skikkelse således Grundtvig en lige så umulig forestilling som menneskeligt liv uden ånd(e).

Naturligvis har Grundtvig som traditionsbåren teolog gjort sig tanker om sjælens vilkår i Mellemtilstanden, perioden fra dødens indtræden til Kristi genkomst. En nogenlunde tilfredsstillende gengiv- 
else heraf har jeg anset for at være for omfattende $\mathrm{i}$ sammenhængen her, der tager sigte på fremtidsaspektet inden for den nærværende tids vilkår. En side af problemkomplekset er omtalt i note 13.

\section{To andre aspekter af Grundtvigs syn på "Sjæl”}

En særlig brug af "Sjæl” forekommer i linjerne fra cirka 1852:

(...) over Porten til Guds-Staden

Med Flamme-Skrift staaer paa Guldpladen

Bekiend din Tro! fornægt dig selv!

Det er den snævre Port for Sjælen,

For det i os, som siger "jeg",

Hvis Ære med den dybe Knælen

Indlysende forliges ei;

Skiøndt intet værd er hvad vi mister,

Os Egenkiærlighed dog frister

Til paa "os selv" at holde fast.

(GSV IV, str. 4-5, 359)

Er billeddannelsen mon foranlediget af en omtrent 40-årig erindring om selvopgøret i 1810-11, hvor Grundtvig gav afkald på en karriere som litterat i København for i stedet at tiltræde som kapellan hos sin far i Udby, nu belyst af et langt livs oplevelser, erfaringer og eftertanke? I givet fald er sjælen infiltreret i noget så håndfast og udadvendt og på en eller anden måde materielt funderet som den samfundsmæssige status, og i hvert fald kommer glosen her betydningsmæssigt meget nær "selvbevidsthed", hvor omverdensrelationen også er en bestemmende faktor.

Værd at bemærke er også valget af "Sjæl” ved oversættelsen af det engelske "mind" i "Gud-Helligaand! O kom" (GSV I, 622-23):

Driv Sorgen fra vor Sjæl

Og Taagen fra vort Øie!

(str. 1, 3-4)

Psykisk/filosofisk kan glosen "mind" indgå som led i "mind and body" (sjæl og legeme; sind og krop) og i "mind and matter" (ånd og materie/stof). I salmesproget hos Grundtvig kan "Sind" dække en stemning eller samstemthed:

Nei, lad os gaa med rørte Sind,

Som Hyrderne, til Barnet ind (...)

(GSV III, str. 15, 128)

Det er saa hyggeligt allensteds

Hvor Smaa og Store har Eet isinde (...)

(GSV IV, str. 2, 413)

"Sind" kan også betegne, hvad vi kunne kalde sjælens inderside: 
Kraften fra det Høie

Os i vort Sind fornøie (...)

(GSV IV, str. 3, 252)

Hvor er Lammet, Offer-Lammet?

Isak spurgte, syg i Sind (...)

(GSV V, str. 1, 172)

Dette særpræg ved "Sind" kan være baggrund for fravalget af denne glose og anvendelsen af "Sjæl" i "Gud-Helligaand! o kom". I sammenhængen her ville "Sind", der ligesom øjet er receptivt/passivt, formindske det energisk/reaktive, der indgår i "Sjæl" som evnen til at svare på, hvad den modtager, og som er væsentlig her. Sammenstillingen sind/øje ville pacificere mennesket på en måde, som ikke er særlig passende i en bøn til Helligånden, der i str. 4 ses som kilde til kærlighed, tro og taknemmelighed:

Neddæmp hos os al Tvivl

Om Jesu Tro og Love!

Indgyd den Kiærlighed,

Som aldrig skal hensove!

At kærligheden er vågen og udadrettet, siger næsten sig selv. Hos Grundtvig er troen det også, eftersom han knytter den uløseligt sammen med bekendelsen som dens udadrettede udtryk:

Ja, troe og bekiende,

Til Dagenes Ende,

Det er Saliggiørelsens Vei (...)

(GSV I, str. 5, 149; V, str. 4, 531)

Da der ikke er nogen begrundelse i rimfølgen til at undgå "Sind", der vel umiddelbart må komme på tale ved læsningen af "mind", ser jeg det aktive i "Sjæl" som anledning til, at netop denne glose er brugt.

\section{"Sjæel", sang og "Støv"}

Temaet "sjæl og sang" er af væsentlig betydning i Grundtvigs salmedigtning. Det ses ikke kun af, at der er tale om et gennemgående motiv i alle digterårene. Da sangen kun kan lyde ved brug af de legemlige elementer lunger, stemmebånd, tunge, mund og læber, er den også med til at knytte "Sjæl" og "Støv" sammen. Derudover viser de nedenfor anførte eksempler, at sangens baggrund er et indgreb udefra. Mere og mere træder det frem $\mathrm{i}$ årenes løb, at dette indgreb er Jesu komme som den, der "er Guds herligheds glans og hans væsens udtrykte billede", for nu at bruge den klassiske formulering fra Hebr 1, $3{ }^{4}$ Sangen er således et modtaget ord, hvor øret, hjertet og sindet har rollen som adgangsvej, og dermed angives endnu en kæde, der forbinder "Sjæl" og "Støv". Sjælen er så at sige støvets mulighed for at blive talt til og vide af sig selv at sige. Også her ville det i dag være 
nærliggende at bruge glosen "selvbevidsthed" til at udtrykke denne side af Grundtvigs syn på sjælen. Støvet på sin side er sjælens middel til at udtrykke sig. I sangen forbindes mulighed og middel, så mennesket er i stand til at svare, når tiltalen fra Guds Ord lyder, altså når Kristus træder ind i menneskets eksistens. I sig selv ejer mennesket ikke evne til at danne sangen. Ertner, 1997, 196-97, citerer NyaarsMorgen, str. 42, 9-11:

Fra Døden til Livet

Kun Een det var givet

Paa Vinger at hæve sig selv.

(US IV, 262)

De følgende, kronologiske opregnede eksempler bringer forskellige udsagn om, at en ekstern instans træder til og udløser sangen.

1811:

Dog, hvi vil, min Sjæl, du forsage?

Hvi bøies, hvi bruser du saa? (...)

[Guds] Lys og [Guds] Sandhed skal føre

Mig op til hans Tempel i Fred,

Der Ordet mit Hjerte skal røre

Og glemme jeg skal, hvad jeg leed;

Ja, selv skal jeg røre min Tunge

Til Psalmer for Herren at sjunge

Til Lov og til Pris for min Gud

(GSV III, str. 6-7, 68)

Selv om det fulde betydningspotentiale i sjæl, hjerte og sang endnu ikke er helt udfoldet i denne strofiske gengivelse af Sl 42-43, er grundelementerne: Guds tiltale og menneskets derudaf voksende svar, ved at forme sig ud fra sprogbrugen i Davidssalmerne.

1817:

Men for af Smaat at giøre Stort,

Af Stort Du her har Lidet giort,

I Krybben lagt, i Klude svøbt,

En Himmel-Seng Du har mig købt!

Velan, min Sjæl! Saa vær nu glad,

Og hold din Juul i Davids Stad!

Ja priis din Gud i allen Stund

Med liflig Sang af Hjertens Grund!

(GSV III, str. 19-20, 128-29)

1825:

Trods klingrende Frost godt Aar I [julens engle] spaae (...)

(...) 
O, synger for dem [børnene] som Lærker slaae,

Som hørt de har ei længe (...)

Da vaagne de mildt i Morgen-Gry,

Og tælle meer ei Timer,

Da nynne de Jule-Sang paany,

Som sig med Hjertet rimer (...)

(GSV I, str. 1, 4 og 6, 405-6)

Når det hedder, at "Vi Rollinger har i hvert et Vraa, / Som Blomster groe i Enge" (str. 4, 3-4), er der ikke kun tænkt på Johan og Svend Grundtvig. Bag dem ses alle mennesker. Uden måske at vide af det, behøver de at høre Guds tiltale for at holde sig selv fast som levende sjæle, en betegnelse, der passer som fod i hose på personerne i str. 4 (Thodberg 1989, 65-66 n).

1836:

Hos dig at bygge, / Høieste Lykke / Kaldes med Ret, Der lyster Tunge / Altid at sjunge, / Vorder ei træt, Til ikke lægger og tager ei fra / Glædens det evige Halleluja!

(...)

Tusinde Døgne, / Verdslige, søgne, / Gyldne for Kiød, Kan de vel ligne / Een Dag af Dine, / Som vi den nød, Naar under Sang, med dit vingede Ord, /

Sjælen afby over Stjernerne foer?

(GSV I, str. 3 og 6, 151)

"Dit vingede Ord" må her være Kristus selv; se omtalen af motivet "Ørne-Vinger" fra "Vai nu, Dannebrog, paa Vove!" (GSV I, 587-589) i afsnittet " "Sjæl", "Støv" og sang (...)" i gennemgangen af "Han, som har hjulpet hidindtil".

At Kristus som den inkarnerede Guds Ord, der er identisk med den Himmelfarne, forener Himmel og Jord, Gud og mennesker, fremgår også af GSV I, 589-90: "Gud-Fader udsendte sit Naadens Ord, / Og Menneske blev den Eenbaarne", hvor str. 2 begynder: "Gud-Fader Han kroned den Mand af Muld, / Og gav ham guddommelig Ære", og sidste strofe lyder:

Vi søge vort Hjem over høien Sky,

Og Englene deres derunder,

Og begge forvente den Verden ny,

Guds Aand kun alene udgrunder,

Da Alting er samlet, som i en Sum,

I Barnet, som lagdes i Krybbe-Rum,

I Himmels og Jords Eenbaarne!

1840:

Følgende strofer fra sangen "Jeg gik mig ud en Sommerdag at høre" 
medtages som eksempel på, at sangen fødes hos "Dødens Folk", "I de dybe Dale", som svar på Kristi nutidige komme, og at dette også tager skikkelse i nadveren, jf. note $4 .^{5}$

Fra Natten da han er forraadt og bryder

Livets Brød til Dødens Folk det lyder:

Tager som det bydes

Legem mit som brydes

Og mit Blod som Jer til Gavn udgydes.

Da fik jeg i mit stille Sind at høre

Fuglesang, som Hjertet kunde røre

I de dybe Dale

Himlens Nattergale

Slog i Chor, som Engle smaa, der tale.

(GSV IV, str. 6-7, 15-14; VI/3, 275)

Om "Sind" i forhold til "Sjæl" se afsnittet "To andre aspekter af Grundtvigs syn på Sjælen".

\section{5:}

Str. 13-17 af "Nat i Østen er ei saa lang" (GSV IV, 209-212) er endnu et udtryk for juleevangeliets betydning for brugen af støv/sjæl/budskab/sang-konstellationen hos Grundtvig, ultrakort sagt sådan:

Kilde-Væld kun er Budskab mit

Til lutter Frydesange,

Thi han, som Jorden giør sjæleglad

Er født til Verden i Davids Stad.

(str. 16, 3-6)

Sammen danner de fem strofer julesalmen "Venner! Sagde Guds Engel blidt" (DDS03, 105).

1851:

I dette år kommer salmen "Alt hvad som Fuglevinger fik" (GSV IV, 290-291) med linjerne:

Min Sjæl, du har af alt paa Jord,

i Tanken og din Tunges Ord

De allerbedste Vinger (...)

(...)

Og det var dig, den [Guds nåde] ledte om,

Da med Vorherrre hid den kom

Paa underligste Maade.

Saa vaagn dog op, min Sjæl, bryd ud

Med Lovsangs Røst, og priis din Gud (...)

(GSV IV, str. 2, 3 og 4, 290) 
Medtænkes "Støvets Vee og Vaande" (str. 1, 6), kan denne salme ses som både det mest kendte og et klassisk klart udtryk for støv/sjæl/budskab/sang-motivet.

\section{4:}

Blandt salmerne fra det ulykkelige krigsår finder vi en ny bearbejdelse af salmen "Min Mund og mit Hjerte" (GSV V, 498-99). Ved ændringerne i str. 2 fra "Med Tungen saa rød" til "Med Ildtungens Glød" er henvisningen til Helligånden tydeliggjort i forhold til formen fra 1837 (GSV I, 264-65). Med Åndens tale er der som på Pinsedag "Lagt Bod for al Vaande / (...) / Lagt Ordet, som frelser fra Død” ind i “(...) Hjerter og Munde (...)". Kristus og hans befriergerning har fundet sin plads i vores liv. Bevægelsen er den samme som i 1 Mos 2,7: "Da formede Gud Herren mennesket af jord og blæste livsånde $\mathrm{i}$ hans næsebor, så mennesket blev et levende væsen”. Befrielsen ved Kristus ses altså i denne salme som en nyskabelse. I str. 3-4 er sangens afhængighed af indgrebet udefra gennem Kristi komme markeret, og det meget tydeligt:
Med Fred og med Glæde
I Faderens Ord
Guds Aand tager Sæde
og Hjertet iboer (...)
Da fødes Lovsangen
Af Hjerte og Mund (...)
(GSV V, str. 3 og 4, 498-99)

For at sangen kan lyde, må "Hjerte og Mund", det hele menneske, den "levende siel", det "Støv", der er beåndet af Gud, modtage Kristus, "Faderens Ord", sammen med "Guds Aand". "Lovsangen", den kristne salmesang, er altså et svar på, ja, næsten et ekko af Gud Faders tiltale i Jesus ved Helligånden.

\section{2:}

Mønstret indgreb/frigørelse/sang møder vi også i Grundtvigs sidste digt, hvor Kristus-forkyndelsen i skikkelsen "Kompas"er den eneste troværdige vejleder,:

Ja, hvor Aanden staaer for Styret,

Og Guds-Ordet er Kompas (...)

Der sig (...) / Aabner Evighedens Port.

Derfor Jesus-Christus-Navnet

Prises skal evindelig,

Af hans Kiærlighed omfavnet

Hjertet er i Himmerig (...)

$(G S V \text { V, str. } 4-5,628)^{6}$ 
I dette afsnit søges det påvist, hvordan det tosidede, men ikke todelte syn, der betragter mennesket som støv oplivet af Guds Ord og Ånd, aftegnes tydeligt, men på forskellig måde i salmerne "Han, som har hjulpet hidindtil" (GSV IV, 272-273) og "Hjertesuk efter Davidsharpen" (GSV V, 49-51). Begge har som baggrund det truede menneskeliv, og begge bruger henvisninger til GT $\mathrm{i}$ både negative og positive udsagn. I de positive udsagn ses Kristusforkyndelsen ud fra Jesu mennesketilværelse inddraget på en måde, som fremhæver dåbens frisættende og håbskabende aktualisering heraf, der fremkalder takkesangen som det for "Sjæl" og "Støv" fælles svar.

\section{"Han, som har hjulpet hidindtil"}

\section{Tekst med strukturnoter}

1. Han, som har hjulpet hidindtil, Han hjelper nok herefter, Han altid kun det Bedste vil, Og Han har Almagts-Kræfter, Og Han saa grundig alting veed, At selv tilbunds i Kiærlighed Seer klart Hans Forsyns-Øie

2. Den øde Ørk, det vilde Hav, Den haarde Vinter-Kulde, Den dybe Sorg, den mørke Grav, De Kiære under Mulde, For alt hos Gud er gode Raad, Til Frydesang han vender Graad, Saa let som Vind og Vove.
7. Og du, mit Støv, hvi sukker du Som under Fjelde knuset?

Du hører jo, der skaffes nu

Dig Plads i Fader-Huset,

Din Frelser vidner, ei et Haar Forkomme skal i Ormegaard Og fattes i Guds Rige!

6. Min Sjæl, hvi bruser du da saa Og krymper dig i Støvet, Og gruer for de Skyer graa For Vindens Pust i Løvet Du veed jo dog, trods Vind og Sky Du skue skal de Himle nye, Som Gud giør evig klare.

5. Vi føler, at hvordan det gaaer, Hvad Verden giør og lader Saa gav os Gud dog Børne-Kaar, Saa er dog Gud vor Fader, Saa er vor Død dog kun et Blund Og Støvet om en liden Stund Faaer ogsaa Ørne-Vinger.

4. Om end vort Støv er lige tungt, Saa faaer vor Sjæl dog Vinger, Saa den med Ordet evigtungt Sig let til Himlen svinger, Og seer saa fra det Høie ned, Med Smil paa Verdens Usselhed Med Trøst paa Jordens Møie. 
3. Thi naar vor Sjæl er i Guds Haand,

Guds-Ordet i vort Hjerte

Da brister for os alle Baand

Som pine kan og smerte,

Da aabner sig, som aldrig før,

Guds-Rigets Port, Guds-Husets Dør

Og Livets Kilder alle.

(GSV IV, 272-73)

Opstillingen ovenfor illustrerer V-strukturen i tekstens indhold. Som det ses, falder salmen i tre afsnit: En tillidspåstand (str. 1-2), en begrundelse for påstanden (str. 3), og en beskrivelse af følgerne af at acceptere påstanden og dens begrundelse (str. 4-7). Påstandens begrundelse udgør salmens vendepunkt, der også kan påvises ved motivfællesskab (sangmotivet) i str. 2 over for str. 4-5 og ved den kristologiske udfoldelse i str. 6-7 af de gudsprædikater, som også forekommer i str. 1. Samlet kan der tales om en modifikation af den opbygning, der er blevet kendt som V-strukturen (Helweg 1978), men med et andet skift end negativ/positiv mellem V'ets to sektioner. I salmen her er skiftet markeret ved en kristologisk intensivering i str. 47 af gudsprædikaterne i str. 1-2. Salmen dateres til tiden under Treårskrigen, altså 1848-51 (Hansen 1966, III, 328).

\section{Salmens tillidspåstand og dens begrundelse}

Str. 1,1 er citat af Sam 7,12: "Så langt har Herren hjulpet os". Ordene falder ved slutningen af en fortælling om en altafgørende sejr over Filistrene, det unge Israels ærkefjender. I tillid hertil ser digteren frem mod, at det samme kan ske igen (str. 1,2), fordi Herren er algod og almægtig. Det kan støtte den anførte datering. Det skiftende kampheld helt frem til Treårskrigens afsluttende fase kunne nok fremkalde ønsket om al mulig støtte. Når der derpå skiftes motiv fra krigens til kærlighedens uigennemskuelighed (str. 1, 5-7), kan det have sammenhæng med, at ikke kun nationens, men også digterens skæbne i disse år havde uklare udsigter. Hans forhold til Marie Toft udviklede sig i denne periode fra "Bekendtskab til et inderligt, ubrydeligt Venskab" (Borup 1943, 204). Samtidig blev det stedse mere tydeligt, at selv om Grundtvig udmærket indså, hvor meget hans hustru Lise havde betydet for ham og hans arbejdsmuligheder, var de gledet fra hinanden, og også hendes tiltagende tungsind havde, uanset årsagerne hertil, efterhånden lagt en dæmper på deres forhold (Borup 1943, 201-9).

Tillidserklæringen i str. 1, 3-5, er formuleret som en kort opregning af de tre klassiske gudsegenskaber: algodhed, almagt og alvidenhed, de to første tilordnet krigen, den tredje kærligheden, men i $ø$ vrigt ganske alment udtrykt. Strofens emnemæssige disposition i $2+$ $\imath+?$ linier oiver den en ligevæet. som svarer til det sprogligt almene 
udtryk, men fastholder en spændstighed gennem afvigelsen fra strofens metriske opbygning i $2+2+3$ linjer.

I str. 2, hvor vanskelighederne formuleres, er udtrykket igen alment, men første linje bruger et ordvalg, der i GT signalerer dødens magt (Pedersen 1920, 354-75). "Den haarde Vinter-Kulde" i 1.2 indeholder måske en allusion til vinterstroferne i Nyaars-Morgen (US IV, 261-62), men kan muligvis desuden være inspireret af Fimbulvinteren, der går forud for verdens undergang, Ragnarok (Bæksted 1972, 192), og hvis optakt Grundtvig lader gribe ind i familieforholdene (Nordens Mytologi 1832. US V, 705). Senere i salmen viser disse udtryk sig at have foregrebet dybt eksistentielle anliggender. Tilliden til Gud i strofens anden del fremtræder også i en ganske enkel formulering, som dog antyder noget mere dybtgående. I 1. 6: "Til Frydesang han vender Graad", anvendes igen stof fra GT (Sl 30, 6b. 125, 5-6). Her antydes det personlige aspekt, som i str. 1 træder frem i skiftet fra krig til kærlighed, og som den enkelte kan træde ind i, så begrundelsen for tilliden til Gud ikke fremstår som teoretisk/filosofisk påstand. Sammen med skiftet fra negativ til potentiel positiv situation $i$ andet halvvers giver også dispositionen $(2+2)+3$ linjer strofen en fin fremadrettethed.

I str. 3 flyttes det, som tynger og truer, afgørende fra det almene gebet til det personlige område. Sjælen i Guds Hånd og Guds-Ordet i hjertet angiver den personlige, positive baggrund for at beskrive negativiteten som "Alle Baand / Som pine kan og smerte", og samtidig markeres menneskeligheden med "i vort Hjerte". Billedet af de snærende bånd er på den baggrund lige ved at gøre fysisk ondt blot ved forestillingen om dem, og vi kan næsten høre det lettelsens suk, der drages ved beskrivelsen af de midler, Gud bruger til at hjælpe med og gennemføre sine gode råd: porten, døren og alle livets kilder, der åbner sig. Også disse udtryk henter betydning fra GT (Port: Sl 24, 7. 100, 4. 118, 19-20. Dør: S1 24, 7. Kilder: Sl 36, 9-10. 87, 7), men også helligstedslegenden om Jakobs drøm i Betel (1 Mos 28, 10-18) må tages i betragtning. ${ }^{7}$ Der er for mig at se heller ingen tvivl om, at talen om sjælen i Guds Hånd og Guds-Ordet i hjertet helt ligetil kan ses ud fra brugen af barnet, favnen og Fadervor som udtryk for Kristus-fællesskabet i Grundtvigs dåbsteologi (Thodberg 1989, 36-38). Port og dør (Thodberg 1989, 29-36) og kilde (Schiøler 2004, 204-205) inddrages også i Grundtvigs metaforik om dåben og Kristus.

Omsvinget bruger således et sprog, der finder næring både $\mathrm{i}$ den aktuelle liturgi på digtets tilblivelsestid og i de gudstjenestlige handlinger ved Jerusalems tempel. På den måde bliver strofens forsynstanke funderet på kristologien og på dåben, som vi også møder det andetsteds hos Grundtvig. Det første kendes fra passagen "Da allerstørst var Nøden, / Du spared ei din Søn" fra "Paa alle dine Veie / Hvor sort det end seer ud" (GSV IV, str. 5, 530. Schiøler, 2004, 183- 
85), og det andet fremgår tydeligt for eksempel af Grundtvigs egen fremhævelse af fredlysningen ved dåben i "Urolige Hjerte! hvad feiler dig dog":

\section{(...)}

Hvad sagde Vorherre

Til dig i din Daab?

Var det ikke Ordet, som passer kun sig

Paa dem, som indtræde i Guds Himmerig?

Var det ikke Ordet "Fred være med dig"?

(GSV IV, 222, 2)

I str. 3 af "Han, som har hjulpet (...)" går det syntaktiske og det metriske forløb hånd $i$ hånd på en måde, der understreger en rolig åbenhed, uden at fremdriften fra str. 2 sættes over styr.

\section{"Sjael”, "Støv" og sang i skiftet fra trussel til trøst}

Den åbnende tolkning af de eksistentielle vilkår str. 3 repræsenterer, griber $\mathrm{i}$ de følgende strofer ind i digterens formulering af vanskelighederne og af den livsmagt, der holder ham oppe. Både vidde og prægnans i sproget øges. Det første viser sig i syntaksens større bredde og i inddragelsen af et mere dynamisk billedsprog. Det andet træder frem i det præg af personlig tiltale, der forstærkes, som digtet skrider frem.

De sidste fire strofer er holdt sammen parvis med hovedvægt på sjælen i den første og støvet i den anden af hvert pars strofer. Derudover ses paralleller mellem det første par over for str. 2 og det andet par over for str. 1. Desuden fremtræder med stedse større tydelighed både kristologiens betydning for både forsynstanken og ligevægten mellem "Sjæl" og "Støv" i antropologien.

Den gennemgående parallel mellem str. 2 og str. 4-5 er sangmotivet: frydesang som Guds mulighed for mennesket $(2,5)$ aktualiseret ved, at sjælen får vinger og med Ordet når Himlen (4, 2-4), og ved, at støvet "om en liden Stund / Faaer ogsaa Ørne-Vinger" (5, 6-7).

"Ørne-Vinger" forekommer flere steder i Grundtvigs salmer. De rummer et opstandelsesaspekt, som er hentet fra Sl 103, 5b: "Du bliver ung igen som en ørn". I Grundtvigs gendigtning af Davidssalmen formuleres det ved hjælp af den ægyptisk-hellenistiske myte om evighedsfuglen Føniks: "Sol-Fuglen lig, bliver ung du igjen!" (GSV I, str. $3,155)$. I to herlige strofer fra "Vai nu, Dannebrog, paa Vove!" (GSV I, 587-589) signalerer sammenhængen støv/ørnevinger/takkesang, at støvets delagtighed i Himlen på lige fod med sjælen udspringer af Kristi Opstandelse og Himmelfart:

Han, der under Vinters-Hjerte

Fødtes under Hytte-Tag,

Han der vaanded sig i Smerte

Under Jævndøgn-Stormens Brag, 
Støvets Søn med Kiød og Blod, Han af Jordens Skiød opstod, Ja opstod, som Blomst udspringer, Stak i Sky paa Ørne-Vinger!

(...)

Føle skal det Folke-Vrimlen, Ja og Amen er Guds Ord, Jorden løftet er til Himlen, Himlen dalet er til Jord, Stigen reist til Engle-Gang Under Støvets Fryde-Sang: Tone-Stigen fra vor Tunge Didop, hvor Serafer sjunge! (str. 3 og 5, mine kursiveringer)

Her er 5, 2 en Kristus-henvisning med brug af Åb 3, 14, introduktionen til det syvende og sidste menighedsbrev. I en strofe fra "Var I ikke Galilæer":

Sandelig, der var Guds Finger,

Som gav Bruden Ørne-Vinger,

Midt i Ørken Huus og Gaard,

Som gav Korsets Ord fra Østen

Kæmpe-Kraften, Kvinde-Røsten

Her blandt os i tusind Aar!

(GSV I, str. 8, 85)

ligger beskyttelsesmotivet fra Åb 12, 24 med forbindelseslinjer bagud til 2 Mos 19, 4 og 5 Mos 32, 11 forrest i betydningspotentialet i "ØrneVinger", men opstandelsesperspektivet fra Fugl Føniks er med. Det indgår gennem "Bruden", der er metafor for den Opstandnes menighed. Den overlever, får "Huus og Gaard", i en ugæstmild, farlig, ja, dødbringende verden: "Midt i Ørken".

I str. 2, 3-4, er "Den dybe Sorg, den mørke Grav, / De Kiære under Mulde" vilkår, der på det personlige plan, over for "Sjælen", bibringes os af verdens handleform: "Hvad Verden giør og lader" $(5,2)$. Realiteten i disse hårde vilkår fornægtes eller formildes ikke, men den får heller ikke lov til at stå alene. Den konfronteres med bevidstheden om "Børne-Kaar" $(5,3)$, og om Gud som "vor Fader" $(5,4)$. Selv opfattelsen af den uundgåelige død kan derved skifte fra fysisk/fjendtlig: "den mørke Grav" $(2,3)$ til en hjemlig/fortrolig: "et Blund" $(5,5)$. Baggrunden er inddragelsen af Kristi Opstandelse og Himmelfart gennem motivet "Orne-Vinger" $(5,7)$ og henvisningen til dåben gennem talen om "Børne-Kaar" $(5,3)$ hos Faderen. Til det sidstnævnte motiv se Thodberg 1989, 52-58.

Som str. 5, 3-5 er orienteret mod verdens handleform, der bringer sorg, død og grav, kan str. 4, 6-7 ses som svar på verdens væreform (str. 2, 1-2). Smil og trøst sættes ind over for det, der gør livet tungt for os på grund af naturens indretning. i "Støvet" "Den ade Ork det vilde 
Hav, / Den haarde Vinter-Kulde" (str. 2, 1-2) er dog ikke éndimensionale metaforer. De er også betegnelsen for "Verdens Usselhed" og "Jordens Møie", de kummerlige vilkår, der følger sliddet for brødet, som det beskrives i 1 Mos. 3, 17-19. Når smil og trøst her er knyttet til, at sjælen svinger sig til Himlen "med Ordet evigungt" (str. 4, 3), er det igen dåbens åbenhed over for det guddommelige, der kommer til udtryk.

Vi har en parallel til, at Frelserens Bøn fra den døbte når op til "Himmerigs Kor" (...) "Og lyder, hvor Englene kvæde" (GSV IV, str. 4, 255). Også de afdøde tager ordet og

Istemme saa lydt

Halleluja nyt

At Englene tie og smile

(str. 6)

Derefter når trøsten gennem nadveren ned til det betrængte Gudsbarn:

Da drypper som Duggen

Der Manna paa Vuggen

(...)

Og klarøiet brat

Du siger godnat

Til Tvivlen og Frygten og Sorgen!

(str. 7)

Det medfører, at Gudsbarnet, den døbte, nu kan vedkende sig Jesusnavnet som betegnelse for ophavet til alt godt, kalde ham "Lyset og Livet":

Sov sødt, Barnlille!

Lig rolig og stille,

Og nyn paa det Navn,

Med Naaden i Favn,

Al Jorden til Salighed givet!

Nyn: Jesus er min,

Saa faur og saa fiin,

Min Jesus er Lyset og Livet!

(str. 8)

(Citaterne følger GSV IV, 255-57. GSV IV, 47-48 har andet ordvalg, ortografi og tegnsætning enkelte steder. Understregningen af Jesusnavnet i $G S V$ IV, str. 8, 156-57, er således ny i forhold til GSV IV, str. $6,48)^{9}$

Bag skiftet fra sorg til glæde, fra frygt til fortrøstning i str. $4-5$ i "Han, som har hjulpet (...)" ligger Kristus-begivenheden, sådan som den føres videre $\mathrm{i}$ dåb og nadver og $\mathrm{i}$ den Jesus-fortælling, der er uløseligt knyttet til dem med dens klimaks i Opstandelse og Himmelfart. Inddragelsen i dette hændelsesforløb gennem den døbtes fremsigelse af Fadervor, jf. note 9, aktualiserer dette omsving fra 
trussel til tryghed under de givne vilkår, som ikke nødvendigvis ændrer sig, i hvert fald ikke det vilkår, at vi skal dø. Sammenstillingen af kristologi og dåbssyn udgør således det kraftfelt, der giver frihed til at leve med de stød, verden giver. Det gælder, hvad enten de rammer på det mentale plan eller det korporlige, på sjælen eller i støvet, eller begge steder i ét hug.

Det sidstes mulighed ville Grundtvig antagelig begrunde med 1 Mos 2, 6-7. Det svarer også til hverdagens erfaring af samspil mellem fysisk velvære og mentalt livsmod. Når det gælder påstanden i kristologien og dåbssynet om en positiv modmagt over for det negative i verden, har "Sjæl" og "Støv" således samme position som både truet og genstand for hjælp.

Gennem dispositionen $1+(1+2+3)$ linjer i str. 4 og $2+(3+2)$ i str. 5 markerer hver strofe vanskelighederne kort og det guddommelige modtræk fyldigt. "Vor Sjæl" (str. 4) fastholder det personlige og "Verden" (str. 5) det almene, men i omvendt rækkefølge i forhold til $\mathrm{krig} / \mathrm{kærlighed} \mathrm{i} \mathrm{str.} 1$.

\section{"Sjæel" og "Støv" som genstand for Kristi befriergerning}

Str. 6-7 bringer efter en højenergisk formulering af de spørgsmål, som i str. 1 har givet anledning til forsikringen om Guds muligheder for indgreb, svar på disse spørgsmål.

De naturbilleder, spørgsmålene formuleres med henter betydningspotentiale i GT. Tilbagekoblingen til Davids Salmer er klarest. Vi har både den brusende sjæl fra omkvædet i Sl 42-43 og den i støvet nedsunkne fra S1 44, 6. Også ormen og støvet fra Sl 22, 7 og 16 er på færde. Brugen af "Ormegaard" i 7,6 inddrager sagnet om Regnar Lodbrogs ynkelige endeligt (Bæksted 1978, 331-32). I alle tre Davidssalmer er salmisten spændt ud mellem fortvivlelse over sig selv og fortrøstning til Gud, helt svarende til digterens position i str. 6-7. Det er rimeligt også at inddrage 1 Mos 3, 14 om den forbandelse, som rammer Slangen: "På din bug skal du krybe, og støv skal du æde, alle dit livs dage", og som lægger op til beskrivelsen af Adams vilkår uden for Eden: hans møje, når han skal skaffe sig føde, og hans tilbagevenden til den jord, han er taget af, når han dør (1 Mos 3, 17-19). "Støvet" i 6, 2 er jo også jordsmonnet, svarende til de andre naturfænomener: "Skyer graa" $(6,3)$ og "Vindens Pust i Løvet" $(6,4)$.

Støvet som genstand for Guds livgivende gerning (1 Mos 2, 7), skyerne som bærer af den himmelske hersker, der kommer til hjælp ( 5 Mos 33, 36; S1 104, 3, jf. GSV III, 506-7, "Sin Vogn giør Han af Skyer blaa"), og vindens pust som metafor for Gud Helligånd som livsfornyer (Johs 3,8) ligger i fortvivlelsens stund uden for digterens rækkevidde. Derfor "krymper" han sig i støvet som slangen, der må krybe på sin bug. Derfor er skyerne grå og ikke hvide, blå eller rødmende som ellers ofte hos Grundtvig. og han "gruer" for dem o 
vinden. Derfor handler "Vindens Pust i Løvet" om efterår og død som i "Skyerne graaner og Løvet falder" (GSV IV, 228-230) og "I falmede Blade! du kiølige Vind!" (GSV IV, 146), ikke om den forsommer, der signaleres med linjerne

Det aander himmelsk over Støvet,

Det vifter hjemlig giennem Løvet,

Det lufter liflig under Sky (...)

$(G S V \mathrm{VI} / 3,268)$

Det sidste naturbillede: "Som under Fjelde knuset" $(7,2)$ lader sig se som influeret af den sten, der i Dan 2, 35 forvandler sig til et bjerg efter at have knust den billedstøtte, som er symbol på verdensmagterne. Digterens elendighed er i så fald i hans egne øjne at ligne ved den, der rammer de ugudelige.

Alligevel signalerer disse truende billeder også håb. De lader sig nemlig bruge i sammenhæng med Kristus. Ormen i støvet tolkes flere steder kristologisk af Grundtvig (Ertner 1997, 194-7, 206-6), og den brusende sjæl har en parallel i evangeliernes beskrivelse af Jesu sindstilstand forud for lidelsen (Matt 26, 38; Mark 14, 34; Johs 12, 27). Stedet fra Johs følges af den himmelske røst om herliggørelsen af Fadernavnet. De grå skyer i strofen

Med den Eenbaarnes Herlighed

Blev Ordet Kiød tilvisse,

Endskiønt Guds Søn kom ei herned

Med Kronen paa sin Isse,

Men fødtes som en Træl i Vraa,

Og døde under Skyer graa

Paa Kors som en Misdæder.

(GSV IV, str. 1, 88)

kan tænkes inspireret af det uidentificerede mørke, der ifølge Matt 23, 45 og Mark 13, 33 faldt over landet, mens Jesus hang på korset. Når Luk 23, 45 tilføjer en solformørkelse, er den et symbolsk forvarsel. Ligesom lyset vender tilbage efter en naturlig solformørkelses "nat $i$ utide", vendte den korsfæstede tilbage fra døden ved daggry "den tredje dag” (Luk 24,1 par). På lignende måde ses skyerne hos Grundtvig ikke som udtryk for Jesu endelige skæbne, men som baggrund for "den Eenbaarnes Herlighed", jf. "Endskiøndt (...) // Men (...)". Stenen i Mark 15, 46. 16, 4 par er heller ikke et sidste ord, når den ses i forhold til Kristus. Selv om “(...) den var meget stor" $(16,4)$, var den væltet fra, da kvinderne nåede frem til graven.

Opmuntringspotentialet formuleres i str. 6,5-7,7 gennem henvisninger til tre med stor selvstændighed og sikker hånd udvalgte passager fra NT. I deres oprindelige kontekst henviser de til tre karakteristiske led i tolkningen af Jesu person. Kristus er ikke kun den korsfæstede Jesus, selv om den korsfæstede Jesus er Kristus. Kristus er 
også den Opstandne og den Himmelfarne. Her møder udsagnene os i omvendt orden. I str. 6, 5-7, tegnes billedet af den nye Himmel og det nye Jerusalem, hvor han er den evigt tronende ( $\AA$ b 21, 1-6). I str. 7, 34 , fortælles om følgerne af, at han er den, der ved at gå gennem døden åbner vejen til "min Faders hus" (Johs 14, 1-7). I str. 7, 1-7, er han den, hvis jordiske færden aftegner fællesvilkåret for dem, der er knyttet til ham (Matt 10, 24-31). Samtidig konverteres den neutrale omtale i str. 1, 3-5 af gudsegenskaberne til en eksistentielt vedkommende tiltale som baggrund for ændringerne af holdningen til følgerne af negativiteten i de gældende vilkår. Det sker tekstligt elegant ved at bruge opregningen i str. $1 \mathrm{i}$ omvendt orden: "Du veed (...)", ikke fra dig selv, men ud fra "Guds-Ordet i vort Hjerte" (str. 3, 2), at du skal se "de Himle nye". "Du hører (...)", at adgangen til Guds Rige er åbnet, noget et menneske ikke kan tiltvinge sig, men det er indtruffet: "Da aabner sig, som aldrig før, / (...)" $(3,5)$. "Din Frelser vidner (...)", at intet er for småt til at høre hjemme hos Gud (7, 5-7). Den tre-leddede, personlige tiltale henviser til den traditionelle teologis tre klassiske gudsegenskaber alvidenhed, almagt, algodhed. De var også på færde i str. 1 (se rubrikken "Salmens tillidspåstand (...)", 2. afsnit), men nu er der ikke mere tale om neutral opregning. Tekstens indtræden i den personlige tiltales rum understreges yderligere ved intensiveringen fra det almene ("Du veed (...)") over det individuelle ("Du hører (...)") til det eksistentielle ("Din Frelser vidner (...)").

Videreførelsen af motivet himmel: "til Himlen" / "de Himle nye" (str. 4/6), giver sjælen en anden udsigt end det bogstavelige, tørre støv, jordsmonnet. "vor Fader" / "Fader-Huset" (str. 5/7) giver tilsvarende støvet en anden betingelse end at være bundet til naturfænomenerne. På den måde fastholder teksten, at det nutidigt/forgængelige, støvet som fjelde, jord, løv, skyer, og det tidsuafhængige/evige: de nye himle, Fader-huset, Guds Rige, har fælles afhængighed af Gud. Den afhængighed gælder derfor også i lige grad "Sjæl" og "Støv", de antropologiske betegnelser, der bruges inden for denne ramme. Også på den vis er de to ligeværdige.

Også i str. 6-7 er den indre disposition præget af øget plads og større intensitet, hvad angår de positive udsagn, her i kristologisk dragt., Str. 6 har $(2+2)+3$ linjer, str. $72+(2+3)$. Derved indlejres en befriende styrke i disse afsluttende strofer. Det giver nyt livsmod i sindet og åbner for ny handlekraft $i$ det praktiske rum.

Når det først er i det afsluttende strofepar, sjælens brusen og støvets suk inddrages, peger det i retning af, at der for Grundtvig findes afgørende spørgsmål, hvor det ikke er holdepunkt nok, at Gud med sit forsynsøje gennemskuer vores tilværelse, hvis vi da skal kunne bære disse spørgsmåls fulde vægt uden at blive knust af dem. Vi kan kun leve med dem, når vi samtidig inddrages i Guds kærlighed, som det skete for Jesus, da han færdedes på jorden. Uanset hans erfaring af 
at være forladt, var Gud ham nær også i den dybeste nød og i døden (Thodberg 1989, 99-100; Ertner, 1997, 196-97). Grundtvigs personlige baggrund for dette evangelisk begrundede syn er antagelig kriserne, den i 1810-11 og dens overvindelse, digterisk beskrevet i NyaarsMorgen, 1824, str. 37-43 (US IV, 260-62 med opfølgning i str. 44-76, sstd. 262-71), og dem i 1825 (Thodberg 1989, 65-67) og i 1844 (Ertner 1997, 200-206. Thodberg 2005, 38-67, m. tekster: Grundtvig-Studier 2005, 68-85, v. Jette Holm).

Omtrent fem år senere, da nye kriser, folkeligt og personligt, trænger sig på, bruger han de vundne indsigter til (igen) at pege på Kristus i dåben som den instans, hvor ordet lyder til hver enkelt om den Guds kærlighedsgerning, som bærer igennem alt. ${ }^{10}$

\section{"Hjertesuk efter Davidsharpen"}

I midten af 1850'erne møder vi dette digt, hvor "Sjæl" og "Støv" igen bruges på en måde, der minder meget om den antropologiske anvendelse i GT, et indtryk, der understreges af henvisningen til Davids Salmer.

\section{Tekst med strukturnoter}

1. Min Gud! kom din Tjener, den gamle ihu!

Det lakker ad Enden: forlad ham ei nu!

Til Dig jeg raaber,

Du levende Gud!

Paa dig jeg haaber,

Du trofaste Gud!

I Vorherres Jesu velsignede navn.

2. Seer $\mathrm{Du}$, hvor ved Støvet min Sjæl hænger fast!

Forsmægte den maatte, om Støvtraaden brast;

Til Dig jeg raaber, (...)

3. Vil Du, da til Trods for al Verden Du kan

Forklare i Aanden det lille Støvgran

Til Dig jeg raaber, (...)

4. See, saa løser op Du for Sjælen i Fred,

Det Støv følger med, som den fast hænger ved;

Til Dig jeg raaber, (...)

5. Jeg troer, Du igrunden alene er god,

Lad Englene see, Du din Skabning forstod!

Til Dig jeg raaber, (...)

6. Bønhør! Blæs paa Støvet igien dog engang,

Saa Englene høre dets yndige Klang!

Til Dig jeg raaber, (...)

7. Hold Ord! Du har sagt, Du med Aand og med Ord

Fornver den gamle. brøstfældige Jord: 
Til Dig jeg raaber,

Du levende Gud!

Paa dig jeg haaber,

Du trofaste Gud!

I Vorherres Jesu velsignede Navn.

(GSV V, 49-51)

I digtet her synes en struktur på færde, hvor en problemstilling, der rejses i str. 1, kommer tilbage i ny belysning til slut, efter at en vending er indtrådt i str. 4. Derfor er teksten opstillet, så den parvise sammenhæng mellem stroferne markeres. Den fremgår af "gamle" i str. 1 og str. 7, "Støvet" i str. 2 og 6 og "forklare"/"Lad (...) see" i str. $3 / 5$. Den symmetriske opbygning taler for, at str. 4 ses som digtets omdrejningspunkt. Dette støttes af den lettelse, der spores i strofens sprogføring ved brugen af den gamle eufemisme for døden: "Du løser op", endda "i Fred". Alligevel fastholdes den anråbende klang fra str. 1 gennem hele digtet, støttet af omkvædet og uanset de mere lærebestemte udsagn i str. 3 og 5. Digtets samklang med Davids Salmer er umiskendelig, selv om det ikke gendigter bestemte passager herfra, men alene bruger deres sprog. Den ydre form med en fremadskridende tankegang afvekslende med et fast omkvæd kendes i næsten trættende længde fra Sl 136 og i kort udgave fra Sl 118, 1-4 (se også Hansen III, 343-44).

\section{Fallesmotiver og forskelle i de tre strofepar}

I hvert af de tre strofepar, som omgiver centralstrofen, str. 4, er der et fællesmotiv og en forskel. Det fælles motiv i str. 1/7 er tidens hærgen. Både mennesket og verden er gamle. "Det lakker ad Enden" for tjeneren (str. 1), og jorden er "brøstfældig" (str. 7). Forskellen er, at truslen om afslutning i str. 1 udskiftes med tilliden til Guds løfte om fornyelse i str. 7. Begge steder ses åbenlys eller hentydende brug af udtryk fra Davids Salmer. I str. 7 er der tale om åbenlys anvendelse af Sl 104, 30:

Du sender din ånd, og der skabes liv,

Du gør jorden ny.

Den angst, der præger str. 1, gør det på den baggrund rimeligt at se "Det lakker ad Enden; forlad ham ei nu!" som en fri hentydning til S1 104, 29:

Du skjuler dit ansigt, og de forfærdes,

Du tager deres ånd bort, og de dør og bliver til jord igen

At Gud skjuler sit ansigt og tager menneskets ånd tilbage, altså gør det modsatte af, hvad der sker i 1 Mos 2, 6-7, er det samme, som at han forlader mennesket, går sin vej. Det er døden.

Som det fremgår nedenfor, er str. 2 bestemt af S1 119, 25. Derfor 
må det være rimeligt, at man også i str. 1 kan inddrage denne Davidssalme. Til belysning af den gamle tjeners behov for hjælp i str. 1, 1 kan anføres Sl 119, 17:

Gør vel mod din tjener, så jeg må leve

Da vil jeg følge dit ord

og tilsvarende kan Sl 119, 28.31b:

Min sjæl er plaget af bekymring,

Rejs mig efter dit ord!(...)

gør mig ikke til skamme!

medtages som baggrund for str. 1, 2, der begrunder behovet for hjælp. Udsagnene fra Sl 119 kommer på tale som en parallel på det personlige plan over for det almene udtryk i Sl 104, 29-30. Disse vers citeres ikke direkte, men kan ses som en forudsætning, der først røbes i str. 7. Enkeltsjælens bekymring (S1 119, 28) som en del af helhedens forfærdelse (S1 104, 29) passer med, at digtet begynder i den personlige, individuelle nød, men skifter til trøstende udsagn, hvor "Sjæl" og "Støv", mennesker og engle, ja "den gamle, brøstfældige Jord" holdes sammen "med Ord og med Aand" (str. 5-7). Dette skifte fra nød til trøst, fra sjælen og støvet som det skabte individ i dets forladthed, til den fornyede skabnings indfældethed i den universelle helhed, sættes i gang i str. 4 med bemærkningen om, at "Sjæl" og "Støv" følges ad, når Gud "løser op", altså tager hånd om døden. Derved træder denne strofe igen frem som digtets omdrejningspunkt.

Bevægelsen fra trussel til tryghed gentager sig i str. 2/6. Det fælles motiv er her "Støvet". Forskellen viser sig i, at sjælen i str. 2 kan risikere at miste sin grobund i støvet. Den "forsmægter", hvis denne sammenhæng brydes, mens beåndingen af støvet i str. 6 fremkalder "dets yndige Klang". Grundlaget for sjælens svar på Guds tiltale er nu genskabt, jf. sjæl/sang/støv-konstellationen og dens funktion i afsnittet herom under gennemgangen af "Han, som har hjulpet hidindtil", str. 45.

Formodningen om brug af motiver fra S1 119 befæstes i str. 2,1 om sjælens afhængighed af støvet. Her er tydeligt tale om inspiration fra Sl 119, 25:

Min sjæl klæber til støvet

Hold mig i live efter dit ord!

Desuden melder S1 119, 170-72 med motivet bønhørelse/lovsang sig ved læsningen af str. 6:

Gid min tryglen må komme til dig,

Red mig efter dit ord!

Fra min læbe strømmer lovsang

For du lærer mig dine love.

Min tunge skal lovsynge dit ord, 
For alle dine befalinger er retfærdige.

"Støvtraaden" i str. 2,2 erindrer om genistregen "Støvtraade-Værket Du kommer ihu!" fra oversættelsen af Sl 103 (GSV I, 155-56).

I str. 3/5 er forskellen knap så udtalt som i str. $1 / 7$ og 2/6. Troen, der hæfter sig ved Gud som den algode (str. 5), kan dog siges at være en mere positiv bestemmelse end bønnen (str. 3). Selv om den sidste er knyttet til Guds almagt, forudsætter den jo mangel på den forklaring, som er strofeparrets fællesmotiv. I str. 5 foreligger denne forklaring og skal alene forelægges de himmelske skabninger. Livet er set som en gåde, Gud må kaste lys over, hvis den skal lade sig forstå såvel timeligt som evigt. I "Forklare i Aanden", str. 3.2, gemmer der sig desuden en henvisning til den ligedannelse med den Opstandne, som andetsteds hos Grundtvig formuleres: "Og naar vi med ham forklares, / Som os fødte her paany (...)" (GSV IV, str. 9, 345). Det forstår end ikke englene umiddelbart.

Guds almagt træder frem i str. 3,1, algodheden i 5,1, og med det erkendelsesmæssige aspekt $i$ "Forklare" og "Lad (...) see" er alvidenheden på færde i begge strofer. Samlet finder vi således de samme teologiske elementer som i "Han, som har hjulpet hidindtil", str. 1, 3-5:

Han altid kun det bedste vil

Og Han har Almagts-Kræfter,

Og Han saa grundigt alting veed (...)

Men bortset fra algodheden $(5,1)$ er gudsegenskaberne i "Hjertesuk (...)" formuleret mindre lige ud ad landevejen. Alvidenheden $(3,2 / 5,2)$ er udtrykkeligt beskrevet som ikke umiddelbart tilgængelig for hverken jordiske eller himmelske skabningers opfattelsesevne. Forklaringen sker "i Aanden" for de førstes vedkommende, og englene skal have den forelagt. Almagten kommer frem på en meget kantet måde: "(...) da til trods for Alverden du kan (...)" $(3,1)$. Måske kan der i sammenhæng med digtets omsving i str. 4 ses en forskydning i positiv retning deri, at almagten (str. 3) før Åndens medvirken lader sig kritisere som vilkårlighed hos Gud, mens et muligt spørgsmål om algodhedens (str. 5) påståede manglende gennemslagskraft i samme situation lader sig returnere til spørgeren med henvisning til dennes egen eventuelle blokering af den ud fra selvcentrerede bevæggrunde. ${ }^{11}$

\section{Et omsving og et omkvaed}

Når digteren i str. 4 kan se døden i øjnene med accept, digtets afgørende omsving, skyldes det den sammenhæng, Gud med sine muligheder, indsigt og godhed kan sætte mellem "Sjæl" og "Støv". Formuleringen i str. 4 er næsten et direkte citat af Sl 119, 25 i oversættelsen fra Grundtvigs ungdom: "Min siel henger ved støv" (AO 1740). Sammenhængens kristologiske aspekt er foruddiskonteret i str. 3 med "Forklare i Aanden". der ud over at rumme indsiotsasnektet 
som omtalt ovenfor peger hen på fællesskabet med Kristus i Opstandelsen.

At det er den gamle skabning, der gendannes, fremgår af digtets videre forløb. "Blæs paa Støvet" i str. 6 henviser til Adams skabelse (1 Mos 2, 6-7) som forbillede, og i str. 7 inddrager udsagnet "med Aand og med Ord" både skabelsesordet og skaberånden fra 1 Mos 1, 2-3 samtidig med, at formlen "med Aand og med Ord" må henvise til talen om Kristus som Guds Ord og Helligånden som kronvidne om Kristus (Johs 1, 14 og 15, 26-27).

Det fremgår af, at den samme bevægelse med en tilsvarende brug af S1 119, 25 ses i salmen "Med Sorgen og Klagen hold Maade" (GSV IV, 77-79; VI/2, 287), som Grundtvig gennemskrev i 1864 til brug for Festsalmer. Frelseren husker her, at "ved Støv hænger du" (str. 5). Derefter lyder det: "Guds Ord, det gaaer aldrig af Minde" (str. 8), og selv om glosen Ånd ikke forekommer, er sagen til stede, fordi salmen slutter med, at mulden ligesom i 1 Mos 2, 6-7 omdannes til livsvæsner, altså indblæses ånd:

Lyksaligste af alle Dage,

O Muld! naar af dig mylre frem

Guds Billeder alle saa fage!

Da Børnene Gud henter hjem!

(str. 11)

Også "At sige Verden ret Farvel” fra først i 1840'erne (GSV IV, 124126) bringer denne motivsekvens. S1 119, 25 citeres: “(...) / Ved Støvet hænger dog min Sjæl, / (...) / “ (str. 4), og Ordet og Ånden er den frelsende faktor:

O lad mig i min sidste Stund

Det høre af din egen Mund,

Som Aand og Liv kan tale (...)

(str. 8)

Støvets sammenhæng med sjælen, når det dødsdræbende og livgivende ord har lydt, træder frem også her i det kendte og håndgribelige billede “(...), at du Stol har sat til mig / I dine lyse Sale" (str. 8).

Digtets kristologiske aspekt, der støttes af disse to salmer, foregribes $\mathrm{i}$ betegnelsen "den gamle" om tjeneren, når den sammenholdes med den diskrete, men virkningsfulde henvisning til Simeon i Luk 2, 25-32 i str. 4. Om den mand, der siger "Herre, nu lader du din tjener gå bort med fred efter dit ord / For mine øjne har set din frelse (..)", hedder det, at "Helligånden var over ham", og at han var "tilskyndet af Ånden". Han fremtræder som en bedaget herre, kalder sig "din tjener" og ser frelsen som "beredt for alle folk", et universelt anliggende, der er trådt frem med "barnet Jesus".

Også her i str. 4 anes dåben i baggrunden som frelserens fredsskabende møde med det nutidige menneske. Eksempelvis kan der igen 
henvises til de for Grundvigs dåbssyn centrale salmer "Sov sødt, Barnlille" (GSV IV, 47-48 og 255-257; V, 529) og "Op til Guds Huus vi gaae" (GSV V, 171-172). Fredens plads i Grundtvigs dåbssyn belyses nøjere i Thodberg, 1989, 104-117.

Utilsløret kristologisk er omkvædets afsluttende linje: "I Vorherres Jesu velsignede navn", en formulering, hvis smukke balance med påkaldelsen af den levende, trofaste Gud i omkvædets korte linjer befrier udsagnet fra både påtrængende sentimentalitet og sentimental underlegenhedspositur. Den renfærdige holdning har antagelig sine rødder netop i brugen af "Davidsharpen". De korte linjer minder i holdning i høj grad om Sl 119, 145-147. 149:

Jeg råber af hele mit hjerte, svar mig Herre (...)

Jeg råber til dig, frels mig (...)

Tidligt om morgenen råber jeg om hjælp (...) (...)

Hør mit råb i din godhed,

Herre, hold mig i live ved dine bud!

Også Sl 130 kommer på tale. Sammen med brugen af Sl 104, der er åbenlys i str. 7 og står i baggrunden af str. 1, af vers fra S1 119 i de lange linjer i str. 1, 2 og 6 og anvendelsen af omkvæd som i Sl 118 og 136 taler det for, at det især er sidste del af "Davidsharpen", digteren har udnyttet, da han skrev sit "Hjertesuk". ${ }^{12}$

\section{"Sjcel" og "Støv" som afhcengige af And og Ord/Kristus}

Hvad angår synet på forholdet mellem "Sjæl" og "Støv" i digtet, er str. 2, 4 og 6 afgørende. Uffe Hansen konkluderer, og inden for digtets rammer efter min vurdering med rette: "Det er for Grundtvig meget magtpaaliggende, at Sjæl og Legeme ikke maa skilles ad, de hænger fast ved hinanden, saa de maa følges ad baade i Døden og i Opstandelsen til det nye Liv i Herligheden" (Hansen 1966, III, 344ø). ${ }^{13}$ "Hjertesuk efter Davidsharpen" viser, at uadskilleligheden er forankret i Gud som den, der bærer alle muligheder, al godhed og al indsigt i sig, og med sin Ånd henvender sig til sin skabning i sit Ord, den sproghandling, der træder frem i det liv, som blev levet af Jesus fra Nazareth, siden kaldet Kristus. I betragtning af, at omkvædets gentagne og derfor digtets sidste udsagn lyder:

I Vorherres Jesu velsignede Navn

lader "Ord" sidst i str. 7,1 sig ikke læse i sin hele betydning uden inddragelse af Johs 1, 14.

I digtet er sjælens og støvets gensidige afhængighed en specifikt teologisk begrundet anskuelse. Den fælles afhængighed af Gud gennem Guds Ånd og Guds Ord er knyttet til både skabelsen og genløsningen. Digterens filosofiske jeg ville formentlig hævde, at den også, hvad skabningens fremtræden angår, svarer til, hvad vi kan indse 
med vores sunde menneskeforstand. Deri kan man støtte filosoffen. I hvert fald er psykisk betingede maveonder, mismod på grund af materielle vilkår, for ringe så vel som for rigelige, og, på den modsatte side, velværet ved varmt bad, god mad og sund søvn efter veludført dagværk velkendte fænomener. Flere og mere komplicerede fænomener kunne opregnes.

Accept af digterens teologiske tolkning vil hvile på tilslutning til omkvædets sidste linje: at livet i sidste ende bæres oppe af en ekstern instans, vi har frihed til at sætte et bestemt navn på. Ved understregningen “i (...) Jesu (...) Navn" gøres kristologien til conditio sine qua non eller, om man vil, til stenen i skoen for gyldigheden af salmens forsynsforståelse. Det kristologiske aspekt er også afgørende i den lille, nu af salmebogen udeladte forsynssalme "Intet saa stort, Han det jo kan", der er omtalt i note 11 .

Præcist formuleres den kristologiske forsynsforståelse endvidere i salmen, der er omtrent samtidig med "Han, som har hjulpet hidindtil" og indledes med strofen

Est du modfalden, kiære Ven,

Som tror dog paa Guds Søn,

Og beder i hans Frelsernavn

Hans egen Barnebøn

(GSV IV, str. 1, 210)

Uanset mellemregningerne $i$ str. $2-5$ er disse indledende linjer bestemmende for, at de senere strofer

Guds Ærende gaaer hver en Storm,

Om den er nok saa vild,

Og ihvor gal den bryder løs,

Ham tjener dog hver Ild!

Og naar al Verden kaster Lodd

Om Ære, Liv og Gods

Udfaldet staaer dog i Guds Haand,

Hans Engle staaer derhos

(str. 6-7)

giver mening. Den i dem udtrykte forvisning om, at Gud i sin godhed ikke under nogen omstændigheder mister sit tag i tilværelsen henter sit sprog i S1 104, 4:

Du gør vindene til dine sendebud

Og den flammende ild til dine tjenere.

Gennem henvisningen til Kristus omstøbes denne overbevisning om en skaberguds magt over naturen til en eksistentiel tryghed over for omverdenen: 
Og troer du paa den Kiærlighed,

Han elsker Støvet med,

Da læg og reis dig i Hans Aand,

Vær ei for Trudsel ræd!

(str. 8)

Troen er jo troen "paa Guds Søn” (str. 1), der som gave i sig gemmer "Gud- Faders Aand / Med Jesu Barne-Daab" (str. 9, 3-4). Her betegner "med" den ledsagende, men tillige nødvendige omstændighed, at vi i vor dåb kaldes "Guds Børn", helt svarende til, at Helligånden steg ned over Jesus, da Himmelrøsten lød ved hans dåb: "Det er min elskede søn, i ham har jeg velbehag!” (Matt 3, 16-17par). Trækkes dette perspektiv, identiteten mellem den døbte og Kristus som Guds børn, ud af Grundtvigs forsynsforståelse, bliver den til tom snak eller "mahomedansk" skæbnetro.

\section{Slutvignet}

På baggrund af et erindringsbillede, citater fra to "håbstekster" og læsningen af hovedteksterne søges en modifikation af Niels Bohrs komplementaritetsbegreb taget $\mathrm{i}$ brug som nøgle til anvendelsen af udtrykket "det kristne håb" om forsynstankens frisættende potentiale hos Grundtvig. ${ }^{14}$

\section{Lyset, liljen og livet}

Som illustration af sjælens og støvets interaktion hos Grundtvig kunne man bruge episoden med den tændte kerte i hans studenterhybel i 1804, der fik ham til at forestille sig døden som det mørke, der er det eneste tilbageværende, når kerten er brændt ned og lyset uigenkaldeligt gået ud (US I, 63): kerten som legemet, flammen som sjælen, lyset som livet. Sjælen er kun til, og livet lader sig kun leve, når kertens voks og luftens ilt, der i billedet må sammenstilles med Guds skabende og genoprettende Ånd og Ord, mødes. Da bliver det lys til, livet, der giver mening og indhold til både kerte og flamme, krop og sjæl. Vi bringes i nærheden af billedet på de dødes Opstandelse fra omdrejningsstroferne, str. 7-9, i sangværksversionen af indledningsdigtet fra Paaske-Liljen:

Paaske-Blomst! Men er det sandt,

Har vi noget at betyde?

Er vort Billed-Sprog ei Tant!

Kan de Døde Graven bryde?

Stod "Han" op, som Ordet gaaer?

Mon "Hans Ord" igien opstaaer!

Springer klart af gule Lagen

Livet frem paa Paaske-Dagen? 
Kan de Døde ei opstaae,

Intet har vi at betyde,

Visne maa vi brat $i$ Vraa,

Skal ei nogen Have pryde;

Glemmes skal vi under Muld,

Vil ei Vokset underfuld

Smelte, støbes i det Dunkle,

Og som Lys paa Graven funkle!

Paaske-Blomst! En Draabe stærk

Drak jeg af dit gule Bæger,

Og som ved et Underværk,

Den mig hæver, vederkvæger,

Svane-Vinge, Svane-Sang,

Synes mig af den udsprang,

Vaagnende jeg ser de Døde

I en Paaske-Morgenrøde!

(GSV I, str. 7-9, 546-47, min kursivering i str. 8, digterens egen i str. 7)

Denne formulering af en transformationsmulighed over for digterens egen og erindringsbilledets frygt for mangel på åbenhed i forhold til den fremtid, der rummer døden, fanger i sin realisme: at det sker "i det Dunkle”, ikke selve den indgangs- og éngangshændelse, støbningen og antændelsen af lyset udgør. Her er digtet i overenstemmelse med, at intet menneske var med ved verdens begyndelse, kun bevidstløse soldater, der "blev som døde" (Matt 28, 5), var i nærheden i det afgørende øjeblik ved Jesu grav, og ingen kan se bag om dødens grænse eller universets yderste, fælles horisont for rum og tid.

Der er hos Grundtvig heller ingen selvbærende, udødelig sjæl fra evighed af, som kan kompensere herfor. Der er alene henvisningen til det livsbærende potentiale i tilværelsen, der hos mennesker formulerer sig sprogligt og derved virker ind på dagligdagen. Hos Grundtvig, som i den øvrige kristendom, træder det frem i talen om Guds indgriben i Skabelsens Morgen, ved Jesu Opstandelse og ved Tidernes Ende, som det hedder hos ham i 1837:

Dødning-Gud er ei vor Drot,

Han er Livets Herre (...)

(GSV I, str. 557)

For mig at se falder det $\mathrm{i}$ god tråd med, at Jesus i en diskussion med nogle saddukæere om de dødes opstandelse konkluderer: "[Gud] er ikke Gud for døde, men for levende" (Matt 22, 33b).

\section{Året, tiden og høsten}

I erindringsbilledet fra studenterhybelen er forestillingen om kertens udbrænding som parallel til vores død den eneste indgangsvinkel til tolkning af synet. I Paaske-Liljen er blomstens visuelle fremtræden sunnleret med sætningen: “( ...) en Draabe stærk / Drak jeg af dit gule 
Bæger" som komplementær indgangsvinkel. Den eliminerer ikke synsindtrykkets ligefremme oplevelse af blomsten som forårstegn, men lader dog digteren se åbenheden over for den fremtid i den menneskelige eksistens, blomsten også er repræsentant for jf. det Vi, der i str. 7,2 og 8,2 identificerer blomsten og digteren. ${ }^{15}$

I høstsalmen "Nu falmer Skoven trindt om Land", 1844 (GSV IV, 50-51), møder vi som komplementaritetens ene iagttagelsesposition en kombination af natur og historie i stroferne

For HØSTEN HER og Høsten hist

Vor Gud ske Lov og Ære,

Som ved Vorherre Jesus Krist

Vor Fader ville være.

Hans Aand, som alting kan og veed,

I DISSE KORTE DAGE

Med Tro og Haab og Kjwerlighed

Til Himlen os ledsage!

(GSV IV, str. 9-10, 51)

Fremhævelserne er mine. Versaler angiver "Støvet", menneskets indfældethed i natur og historie. "(...) disse korte Dage” kan have erfaringsgrundlag i salmens tilblivelsestidspunkt op mod efterårsjævndøgn, hvor dagens afkortning er mest tydelig. Året var 1844. Også det modne menneskes oplevelse af øget acceleration i tidens forløb har muligvis spillet ind. Grundtvig var som bekendt fyldt tres i 1843. Begge forhold lægger op til den eksistentielle alderdomserfaring og dens tydning, vi møder i "Hjertesuk efter Davidsharpen".

Kursiv viser det åbenhedspotentiale, der aktiveres ved, at mennesket også er "Sjæl", genstand for tiltale og i stand til at tyde den. Skiftet fra iagttagelse til tydning indtræder i salmens str. 6-7, der bestemmer tydningen af "høst" i "Høsten hist" over for "Høsten her". Den kalendariske vending "Og efter Vinter kommer Vaar / med Sommer, Korn og Kjerne" (6, 3-4) foregriber den eksistentielle "En evig Sommer hos vor Gud / I Paradis vi finder" (7, 3-4) på en måde, der svarer til "Vinterblomst! du melder Vaar" (GSV I, str. 5, 546), som leder over til, at blomstens betydning, ikke dens nøgne fakticitet, er det afgørende: "Ved mit Syn kun den sig fryder, / Som har kiær, hvad jeg betyder" (GSV I, str. 6, 546) (Grundtvigs kursiv).

Den ikke-fremhævede passage: "Vor Gud (...), / Som ved Vorherre Jesus Krist / Vor Fader vilde være. // Hans Aand, som alting kan og veed (...)", afslører, at tydningen af evangeliets tiltale er en trinitarisk baseret forkyndelse med en kristologisk pointering, hvor korsfæstelsen og opstandelsen er sat $\mathrm{i}$ forgrunden gennem det instrumentale "(...) ved Vorherre Jesus Krist”, jf. for eksempel ApG 2, 36: “(...) den Jesus, som I har korsfæstet, har Gud gjort til både Herre og Kristus”, og hymnen i Fil 2, 2-11. 


\section{Komplementaritet og åbenhed}

I citatet fra Paaske-Liljen med digtets brug af et naturbillede i sammenhæng med Jesus-hændelserne og Opstandelses-prædikenen, i høstsalmen med dens kombination af (års)tidens indtryk og trinitetslærens kristologiske centrum, og i de to forsynssalmer med deres anvendelse af materiale fra GT som baggrund for en tilsvarende kristusforkyndelse optræder en ensartet komplimentaritet (se note 14). Dens ene iagttagelsesposition er i digtet omtalen af en hverdagshændelse, synet af et genkendeligt, botanisk fænomen. I høstsalmen er det vores afhængighed af naturen og tidens gang. I hovedteksterne er den nogle dels fortællende, dels eftertænkende sproglige følger af menneskets erindringsevne. I alle fire tilfælde er den anden iagttagelsesposition én og samme eksistentielle tolkning af den tiltale, Jesusbegivenheden og dens virkningshistorie har kastet af sig i digterens bevidsthed.

Gennem denne komplimentaritet aktualiseres en sproglig åbenhed over for den fremtid, som er uerfarbar både nu, i morgen og så langt, vores forestillingsevne rækker. På den måde mobiliseres et potentiale både over for det mismod og den frygt, som kan spærre for udsynet til omverdenen og for forståelsen af den, og over for det overmod og den skråsikkerhed, som kan låse vores opmærksomhed fast på os selv og samtidig lukke øjnene for egne svagheder. Begge dele forekommer både individuelt og socialt, nationalt og internationalt.

Over for disse vilkår og over for vores yderste grænse, døden, fastholder Grundtvig i de to salmer i ét greb, at der i morgen er en ny dag, og at vi ikke selv er basis for vores eksistens. Han gør det ved at bruge sjæl/støv-komplimentariteten til at sætte ord på sagen. "Støv" som mennesket dannet af "agerjordens muld" (1 Mos 2, 7. AO 1931, som er mere præcis over for det hebraiske adama end AO 1992) medfører, at vi holdes fast på vores indfældethed i natur og historie, mens "Sjæl" som mennesket bestemt ved indgreb udefra, indblæst "livsånde" (sstd.), bevirker, at bevidstheden om de humane tillids- og forundringsevner bevares som forståelsesbaggrund for, at glosen Gud - også - udsiger en bestandigt åben fremtid, hvis karakter kendes fra Guds nutidige indgreb gennem Kristus-begivenhedens virkningshistorie.

Den kristne forkyndelse, vi møder i "Hjertesuk efter Davidsharpen", str. 4, dåben, der dukker op i "Han som har hjulpet hidindtil", str. 3, og nadveren, som nævnes i kirkeudgaven af "Jeg gik mig ud en Sommerdag at høre" (GSV IV, str. 6, 14), repræsenterer hos Grundtvig indgrebet nu til dags fra den aktive eksterne faktor, Gud, se note 4. Henvisningen til forkyndelse, dåb og nadver præciserer på den måde sjæl/støv-komplimentaritetens åbenhedspotentiale over for fremtiden ved at hente udsagnskraft fra efterretningerne om den Jesus, der kaldes Kristıs Det handler ikke om en diffus drøm eller en udspekuleret 
utopi. Det ligger derfor ligefor at kalde denne formulering af forsynstanken "Det kristne Håb".

Forkortelser

AO1740: Biblia: det er den ganske Hellige Skrifts Bøger (16. opl., 1819), København.

AO2003: Bibelen. Den hellige Skrifts kanoniske Bøger (2003), København.

DDK03: Den Danske Koralbog (2003), København.

DDS03: Den Danske Salmebog (2003), København.

DDS53: Den Danske Salmebog (1953), København.

E: Evangelisk-christelig Psalmebog (1798), København. Anv. udgave fra 1803.

FA: Salmebog. Samlet og udgivet af flere Valgmenigheder (1918), København.

FS40: Folkehøjskolens Sangbog (1940), Odense.

GSV I-VI: Th. Balslev et al. (udg.) (1944-66), Grundtvigs Sang-Vark. Samlet Udgave, bind 1-6. København.

HGS I-III: Ernst J. Borup og Frederik Schrøder (udg.) (1929-31), Haandbog i Grundtvigs Skrifter, bind 1-3, København.

KH: Psalmebog for Kirke og Hjem (1897), København. Anv. 39. opl., u.å.

N: Evangelisk-Luthersk Psalmebog for de dansk-talende Menigheder $i$ Slesvig (1889), Schleswig.

SS: Den sønderjyske Salmebog (1925), København. Anv. 4. opl. 1937. US I-X: Holger Begtrup (udg.) (1904-09), Nik. Fred. Sev. Grundtvigs Udvalgte Skrifter, bind 1-10, København.

\section{Litteraturliste}

\section{Værker af Grundtvig}

Balslev, Th. et al (udg.) (1944-64), Grundtvis Sang-Vark. Samlet Udgave, bind 1-6. København.

Begtrup, Holger (udg.) (1904-09), Nik. Fred. Sev. Grundtvigs Udvalgte Skrifter, bind 1-10, København.

Borup, Ernst J., og Frederik Schrøder (udg.) (1929-31), Haandbog $i$ Grundtvigs Skrifter, bind 1-3. København.

\section{Varker af andre forfattere}

Borup, Johan (1943), N. F. S. Grundtvig, København. Bæksted, Anders (1972), Guder og helte i Norden, København. Ertner, Jørgen (1997), "Et ord af Guds Søn”, Grundtvig-Studier 1997, København, 185-211. 
Hansen, Uffe I-III (1937-66), Grundtvigs salmedigtning, bind 1-3, Odense (bd.I) og København.

Helweg, Lise (1978), "Til Glæde for Graad - Om V-strukturen i Grundtvigs håbssalme", Grundtvig-Studier 1977/78, København, 247-259

Koch, Carl (1925), "Mystik og Menighedsbevidsthed", Grundtvigske Toner, 1925, København, 83-103

Malling, Anders I-V (1962-66), Dansk Salmehistorie. Salmerne, bind $1-5$, København

Pedersen, Johs (1920), Israel I-II, København

Polkinghorne, John (1990), Den samme verden. Fysikkens og religionens verdensbillede, København.

Thodberg, Christian (1989), Syn og sang. Poesi og teologi hos Grundtvig, København.

Thodberg, Christian (2005), "Grundtvigs krise i foråret 1844", Grundtvig-Studier 2005, København, 38-67.

Toldberg, Helge (1950), Grundtvigs Symbolverden, København.

Schiøler, Aage (2004), "Den kirkelige anskuelse som svar på Karon", Grundtvig-Studier 2004, København, 179-233.

\section{Noter}

$1 \quad$ På grund af emnets begrænsede sigte og af hensyn til artiklens længde er der afstået fra drøftelse med værker, der i bredere sammenhæng behandler Grundtvigs menneskesyn.

2 Når gloser fra Grundtvig-tekster kan opfattes som termini technici, anvendes citationstegn og oprindelig ortografi.

3 Sædvanligvis bruges $A O 2003$, men hvor oversættelsen er af betydning for forståelsen, anføres $A O 1740$.

4 Skal der anføres et karakteristisk eksempel på, hvordan Grundtvig forestiller sig Kristi komme som nutidig agent i menneskelivet, kommer følgende passage fra hans prædiken på Pinsedag 1862 naturligt på tale:

$\mathrm{Ja}$, mine Venner, Evangeliets Forkyndelse med Daaben og Nadveren, det er ikke blot levende Minder om Frelserens, Vorherres Jesu Kristi Fødsel og Opstandelse og om hans Aands Udgydelser over Apostlene, levende Minder, som avle Haab om Delagtighed i Guds Frelsning; men det er guddommelige Vidnesbyrd og Saligheds-Midler fra Slægt til Slægt, som meddeler alle sandhedskjærlige Hjerter den kristne Tro, det kristelige Haab og den kristne Kjærlighed, med Retfærdigheden, Freden og Glæden i den Helligaand, som er de Kristnes Himmerig paa Jord, saa at glemte eller oversaa vi disse Herrens store Højtider af guddommelig Indstiftelse over de selvgjorte Højtider, som, naar de falder allerglædeligst, dog kun er Skygger af Herrens underlige Gjerninger uden Livskraft, da skuffede vi os sørgelig, som Menneskens Børn altid skuffe sig sørgelig ved at tage Skuespil for Virkelighed, efter Herrens Ord ved Profeten Esaias om dem, der drømme, at de æde 
Skal derfor Jul og Paaske og Pinse, betragtede i Herrens Lys, beholde Navn af kristelige Højtider, da maa de nøjes med at kaldes de smaa Højtider, som pege paa de store; og skjønt de hidtil sjælden eller aldrig har gjort det, saa kan og skal de dog gjøre det herefter i Herrens oplyste Menighed, som gjærne vil have alt muligt til fælles med alle dem, der har trot paa Jesus som Kristus, den levende Guds Søn; men maa henføre alt, hvad den skal kalde kristeligt til Vorherre Jesus Kristus selv, med hans guddommelige Ord og Gjerninger (...)" (HGS III, 171-72).

I de følgende sangværkstekster vil forkyndelsen især dukke op i form af julebudskabet, men også nadveren forekommer. I "Han, som har hjulpet hidindtil" dukker dåben meget tydeligt op i str. 3, og i "Hjertesuk efter Davidsharpen", str. 6, er der muligvis en hentydning til den.

Koch, 1925, er en stadigt læseværdig gennemgang af det særegne ved det citerede digt.

Lovpris, I Herrens tjenere,

Lovpris Herrens navn!

Lovet være Herrens navn,

Fra nu og til evig tid!

Fra øst til vest

Skal Herrens navn lovprises.

med de to navne Jesus og Christus som integreret udtryk for Guds kærligheds nærvær findes allerede i 1849:

Priser I Herren, hans Tjenerskab!

Priser det Navn, som vor Gud os gav

Til Salighed her og i Himlen!

Slaaer, alle Sjæle, til Navnet Lid,

Priseligt nu og til evig Tid

I Engles og Menneskers Bolig!

Jesus, vor Frelser og Christus vor Drot

Hør, det er Navnet, som Alting giør godt,

Det Navn gaaer i Straaler om Solen!

(GSV IV, 243)

Som lokalt og for sin tid typisk eksempel på ikonografisk brug af motivet "Himmerigs Port" kan nævnes inventaret i Nørup kirke ved Vejle. Den blev i 1730'erne restaureret på foranledning af Gerhardt Hansen de Lichtenberg, storkøbmand i Horsens og ejer af adskillige godser i det østjyske. Det prægtige barokinventar stammer fra Jens Jensen Samsøe den Yngres værksted i Horsens og er dekoreret med allegoriske billeder udført af Mogens Thrane, der også har arbejdet i Viborg Søndre sogns kirke. Gennem en dobbeltlåge to trin oppe når man koret med døbefont, alterbord og opgang til prædikestolen. Den ene låge viser i forgrunden Kapernaums ældste, der hos Jesus går $\mathrm{i}$ forbøn for den romerske "høvedsmand" med den syge tjener. I baggrunden ses den renoverede Nørup kirke med det karakteristiske "Lichtenbergske løgspir", og lågens 
indskrift lyder (naturligvis): "Han elsker vort folk og har opbygget os synagogen" (Luk 7, 2-5). På den anden låge afbildes Jakobs drøm med sten og stige og lem i himmelhvælvet. Her er indskriften selvfølgelig: "Her er intet uden Guds huus og Himmelens port" (1 Mos 28, 12-17). Sådan!

Toldberg, 1950, 321, henviser s.v. "Føniks" til flere kombinationer.

Omarbejdelserne af str. 2 i "Sov sødt, Barnlille" (GSV IV, 47-48 og 25557; V 529; VI/2, 29) lader sig se som stadigt klarere udtryk for, at brugen af Fadervor aktualiserer dåben hos Grundtvig. Tilføjelsen af strofen:

\author{
Dit Hoved du bukke! \\ Din Sjæl sig neddukke, \\ For aldrig at døe \\ I Livskilde-Sø \\ Hvor Roser paa Rand ikke falmer! \\ Ved Daaben opgroer \\ Af Paradis-Jord \\ De deilige Evigheds-Palmer. \\ (GSV IV, str. 3, 255)
}

kan, set i relation til den efterfølgende strofe om Fadervor, opfattes som et første stade i arbejdet med at afklare formuleringen af denne forståelse mellem dåb og Fadervor, som når sit endelige og præcise udtryk med linjerne:

\author{
$\mathrm{Nu}$ kan i din Daab \\ Med Saligheds-Haab \\ Sin Sjæl og dit Hjerte sig bade! \\ $(G S V$ V, str. 2, 529)
}

der gør den oven anførte strofe overflødig, idet "Saligheds-Haab" er en art dæknavn for Fadervor hos Grundtvig (se Thodberg 2005, 55-59, 1989, 66-88).

10 Brug af etymologi og grammatik er uundværlig ved tydning og tolkning af enhver tekst. Forholdet mellem syntaks og metrum kan være oplysende ved læsning af strofiske tekster. Højtlæsning kan fremme forståelsen. Det samme gælder forholdet mellem tekst og melodi ved sangbare tekster. Det er i udpræget grad tilfældet, hvad angår "Han, som har hjulpet hidindtil", hvor de tre mest anvendte melodier på hver sin måde er med til at markere tekstens indholdsmæssige struktur.

August Windings charmante romance, skrevet i 1864 til "Som Hønen klukker mindelig" (GSV I, 147-48. DDK03, 476), har et lidt for blidt præg i forhold til de første tre strofers nøgterne ordvalg og passer direkte dårligt til de afsluttende strofers dramatiske holdning.

Henrik Rungs melodi, skrevet 1850 til "Sin Vogn giør Han af Skyer blaa" (GSV III, 506-7. DDK03, 469), rammer bedre disse strofer, men en række melodiske udsving og harmoniske spændinger efter takt 4 forstyrrer det tilbageholdte åndedræt i str. 1-3.

Den stramme Strasbourg-melodi, noteret i 1525, der hos os er knyttet til H. C. Sthens "Et trofast hjerte, Herre min" (DDS03, 679. DDK03, 126), er emotionelt mindre vidtspændende end de to romantiske melodier, men den går godt i spand med de første tre strofers tilbageholdenhed, og 
over for de sidste strofers stærke ord giver den et præcist og opmærksomhedsvækkende modspil.

Har man prøvet at synge salmen til alle tre melodier, kan den opmærksomme deltager i sangen næppe have kunnet undgå at få salmens struktur indlejret $\mathrm{i}$ bevidstheden.

Da salmen kom med i forslagene til KH i 1885, 88 og 92 og i den autoriserede udgave i 1897, blev str. 6-7 udeladt, måske fordi epokens religiøse præg ikke kunne kapere deres direkte dramatik. Når str. 4-5 får lov at slutte salmen, har den mulighed for at udtrykke en art dagligstueteologi, som passede bedre til det sene 1800 -tals mentale indstilling i mange kirkelige kredse. Det kan have støttet den gennemslagskraft, Windings melodi fik. Man kan her også tænke på den yndest, kopier af Thorvaldsens Kristus-figur fra Københavns domkirke opnåede, eller sammenligne med H. Rørdams "Man siger, livet har bange kår" (DDS03 547).

Formuleringen "Guds Ord i Mund og Hjerte" (str. 3,2) indgik i en række salmebøger i 18- og 1900-tallet. Den var blevet optaget i første udgave af Sang-Vark (...), bd. 3, i 1875 (GSV VI/2, 326), men er en unødig og ubegrundet ændring, fordi det beåndede støvs reaktive potentiale "Mund" stilles foran det receptive "Hjerte". Ændringen slører, at mennesket i strofens sammenhæng først og fremmest ses som modtagende i forhold til Gud.

Den brutale, for ikke at sige forvrængende afkortning af salmens perspektiv blev der dog snart rådet bod på. I kongeriget mig bekendt første gang i $F A 7$, måske med baggrund i krigen 1914-18 og kendskab til $N$ 492, der havde medtaget alle strofer. De sønderjyske menigheders vilkår var jo på den tid anderledes trykkende end det københavnske borgerskabs. $N$ retter dog i slutningen til

Din Frelser vidner: Dine Haar

Er talte, og fra Ormegaard

Du kaldes til Guds Rige

(Malling II, 1962, 123. SS 492, 7)

Den noget knudrede form er en svækkelse, også fordi ormegården her lader sig forstå som det "verdslige" liv, hvorfra vi kaldes til Guds Rige. En association til forholdet mellem den preussiske repressionspolitik under det tyske herredømme og muligheden for trods alt at kunne synge danske salmer kan dog næppe udelukkes. SS, som sandsynligvis følger $N$, foreslår melodien til "Nu fryde sig hver kristenmand" (DDK03, 384). Også denne salme handler om Guds indgreb i en kritisk situation. Hos Grundtvig er "Ormegården" tilintetgørelsens eller fortabelsens sted (Matt $10,28)$.

Siden hen er formen med syv strofer taget $\mathrm{i}$ brug i vist nok alle tillæg og forslag til salmebøger i 1900-tallets anden fjerdedel. Den var også med i den vidt udbredte $F S 40$, og kom til at stå overordentligt stærkt i mange syngende danskeres bevidsthed i årene 1940-45. I 1953 og 2003 var den derfor af både indre og ydre grunde selvskreven i Den Danske Salmebog.

11 Muligheden for, at blokeringen over for det gode skulle ligge hos Gud, 
kan udelukkes hos Grundtvig. Et karakteristisk udtryk for hans syn er den lille forsynssalme fra 1849 med indledningslinjerne:

Intet saa stort, Han det jo kan,

Intet saa godt, Han det jo vil (...)

og slutstrofen:

Vilde Han ei, trods Verdens Spot,

Trods al vor Synds Mangfoldighed,

Selv overvinde Ondt med Godt,

Aldrig Han saae til Jorden ned

Mindre Han havde sin Søn os sendt

$\mathrm{Al}$ vor Sorrig med Glæde endt,

Al vor Kvide til Lovsang vendt!

(GSV IV, 243-44)

Fremhævelsen er min. Grundtvigs begrundelse for at hævde Guds algodhed er tydeligt kristologisk centreret.

Med den rette melodi, som tog hensyn til forskellen mellem de lange linjers fremsættende form og omkvædets direkte anråbende karakter, kunne "Hjertesuk efter Davidsharpen" efter mit skøn finde anvendelse som vekselsang ved særlige anledninger, for eksempel på Allehelgens søndag, og som evangeliesalme eller salme efter prædiken på Julesøndag. Den ville dog næppe komme i så almindelig brug, at optagelse i en salmebog ville falde naturlig, men både tillæg og kopimaskiner er i dag mere brugbare redskaber end for 50 år siden.

Jeg skylder Kim Arne Pedersen tak for at have genopfrisket min viden om, at Grundtvigs tale om sjælen har flere idehistoriske kilder end GT.

To tidsmæssigt vidt adskilte tekster røber det. Afslutningen på udredningen om selvbevidstheden i Danne-Virke II, 1816-17 (US 411, 14) lyder: “(...) fordi ingen sand Videnskabelighed kan finde Sted, før vi have en sikker indvortes Erfaring af vor oversandselige Tilværelse, ere os aandelig selv-bevidste, kan bevise, at vi har en Sjoel, bevise den evige Uforenelighed mellem Sandhed og Løgn, forstaae Sandhedens Grundsætning, saa vi kan anvende den paa os selv og paa Mennesket i det Hele". Indre overbevisning, "Kend dig selv", sjælens eksistens, logisk konsekvens og afklaret erkendelse af, hvad der er sandt, følges ad på en måde, som ligger langt fra det gammeltestamentelige: at være "en levende siel". Her er det størstedelen af den vesteuropæiske filosofihistories spørgsmål, som går hånd i hånd, og selvfølgelig har det spillet ind på "Sjæl" som selvbevidsthed i linjer som dem fra "Gud Helligaand, vor Igienføder", 1852/53 (GSV IV, 358-59): "Det er den snevre Port for Sjælen / For det i os, som siger "jeg" (...)" og "Os Egenkiærlighed dog frister / Til paa "os selv" at holde fast" (str. 5, 1-2. 6-7). Alene forskellen på den brede og den stramme form viser dog, at der ligger en lang kritisk og selvkritisk erkendelsesproces mellem de to udsagn.

I andre sammenhænge findes en mere kompliceret støv/sjæl-figur. Der kan i hvert fald lokaliseres tre varianter. De to første: "Kristus i de Dødes Rige" og "De, der døde før Kristus”, er omtalt i afsnittet Sjæel og dødning. Selv om legemet er i graven og sjælen i Dødsriget, kan digteren ikke tonke no tale nm en menneckelio tilværelce uden håde indre liv "Siæl" 
og ydre skikkelse, "Støv", og begge er for ham genstand for Guds opmærksomhed og indgreb. Den tredje støv/sjæl-figur findes i omtalen af dem, der er afgået ved døden siden Kristi Opstandelse.

I den sammenhæng møder vi Kingo-bearbejdelsen "Klar op, mit Hjerte, Sjæl og Sind" (GSV I, 651-53), hvor vi finder et klart lutherskortodokst inspireret synspunkt i str. 9-10. En modifikation heraf findes i "Med os har det slet ingen Nød" (GSV I, 262-63). Begge steder dukker hyrdens stav fra Sl 23, 4 op som næsten fysisk attribut. Ud over at henvise til Jesus som hyrden markerer den en sammenhæng til det nærværende liv. Den forekommer for eksempel i konfirmationssalmen til Meta: "Velkommen, Morgenrøde", 1843: "Den Haand med Bibelstaven / Os trøster i al Nød" (GSV III, str. 5, 447-48).

Mere udførligt er digtet "Liv og Død", 1852 (GSV IV, 377-79), hvor "Sjæl" og "Støv" optræder som separate entiteter. Er "Dødens lange Vinternat" (str. 2,4) her i familie med den "Midvinter sval", der er sprogligt klimaks i str. 39-41 i Nyaars-Morgen, 1824 (US IV, 261), synes den ikke reserveret perioden efter det fysiske dødsfald, men også at kunne indtræde, mens legemet er i levende live. Nok er sjæl og legeme fraværende fra hinanden i Mellemtilstandens erfaringsmæssige vakuum, men "Støv" og "Sjæl" er som antropologiske synsvinkler stadigt henvist til hinanden i den fælles afhængighed af Guds indgreb gennem Ordet og Ånden. Kristologien markeres gennem Grundtvigs fremhævelser i "Liv og Død”: “(...) opvakt i Jesu Grav" (str. 8, 3) og "Livet er (...) // Evigt Liv i Jesu Navn" (str. 9, 2).

Uffe Hansens formulering kunne bringes nærmere til at dække også uden for "Hjertesuk (...)" ved at bruge følgende modificering: Sjæl og legeme må ikke skilles ad. De er gensidigt henvist til hinanden i den fælles afhængighed af Gud, der er afgørende for begge både i livet, i døden og i opstandelsen til det nye liv i herligheden.

Betegnelsen komplementaritet stammer fra den danske atomfysiker og nobelprismodtager Niels Bohr, der brugte den i 1920'erne i forbindelse med fænomener inden for lyslæren. Iagttaget gennem et prisme opfattes lyset som bølger, gennem et krystalgitter som enkeltpartikler, kaldet fotoner. De to iagttagelser kan ikke gøres på samme tid af den samme person, men begge er nødvendige for forståelsen af lysets natur. Denne praktiske komplementaritet er senere gjort forståelig gennem den såkaldte kvantefeltteori. En komplementaritet, der stadig består også teoretisk, følger af Heisenbergs usikkerhedsrelation, som fastslår, at man ikke på én gang kan bestemme en elektrons sted og hastighed (Polkinghorne 1990, 117 og 134 s.v. komplementaritet, kvantefeltteori, ubestemthedsprincip).

$\mathrm{Da}$ Niels Bohr selv har anvendt betegnelsen i afledt betydning (Polkinghorne 1990, 106-7), bruges den her med de forbehold, den ændrede sammenhæng kræver, til belysning af forhold som støv/sjæl, omtale/tiltale, iagttagelse/tydning. Også her er der tale om to adskilte tilgange til én og samme sag, blot er de bestemt af sprogets, ikke af forskellige forsøgsopstillingers begrænsning. Forholdet mellem særpræget ved Jesu ord og optræden og deres virkningshistorie på den ene side, og den eksistentielle tydning på den anden, eksempelvis $i$ brugen af navnet/titlen Kristus og $\mathrm{i}$ den trinitariske oudsforståelse kan efter mit 
skøn også med fordel overvejes ud fra en tillempning af komplementaritetsbegrebet. Historisk-litterære metoder giver ikke det fulde billede af det sagskompleks, kristendommen er, ej heller en isoleret betragtning af den som eksistentielt anliggende. Hver for sig er de to udsagnsarter gyldige, men selv om de ikke kan bringes til at dække hinanden, kan de sammen tegne et om ikke fuldstændigt, så dog mere fyldestgørende billede af sagen "kristendom", end de hver for sig har kapacitet til. “(...) den (...)” i str. 7, 6 må være dråben fra str. 7, 1, da den, så vidt jeg kan se, har samme virkning som den (morgen)dug, der hos Grundtvig forkynder nyt liv og nyt håb, jf. Toldberg 1950, 319, s.v. "dugg”, og GSV V, str. 1, 212: "Som Dugg paa slagne Enge", 1860 og 64, str. 1. Toldberg 1950, 175-79, giver et godt indtryk af bredden i det svanebillede, Grundtvig gennem str. 7, 5-6: "Svane-Vinge, Svane-Sang / Synes mig af den udsprang", lader betegne den åbenhed over for fremtiden, der for ham også rummer Opstandelsen, jf. det fremhævede: Svanerne er den nordiske parallel til Føniks (Toldberg 1950, 178). I to særtryk af PaaskeLiljen, 1817, fra 1859 og 1865 ændres "Svane-Vinge, Svane-Sang" til "Hanegal og Morgensang" (Malling IV 301). Genoplivningsmarkøren hentes nu i Hading-sagnet, jf. Toldberg 1950, 323, s.v. "Hading", "hane" og "hanegal". Se også note 8 . 